\title{
Optional Choice of Court Agreements in Private International Law: General Report*
}

\author{
Mary Keyes \\ Professor \\ Griffith Law School, Griffith University \\ Brisbane, Australia \\ m.keyes@griffith.edu.au
}

\begin{abstract}
The law in relation to choice of court agreements has developed significantly in recent years, but most of this development has concerned exclusive choice of court agreements. Optional choice of court agreements have not been the focus of attention by lawmakers or by commentators. This chapter provides an overview of this area of the law, synthesising the national reports which comprise this collection, and drawing out the themes that emerge from those reports. It shows that the legal treatment of optional choice of courts differs substantially between legal systems, and argues that this topic warrants greater attention from scholars and lawmakers.
\end{abstract}

\section{Introduction}

One of the most radical recent changes in private international law internationally is the development of the law in relation to the effect of choice of court agreements. Until recently, jurisdictional litigation was less common than litigation on the issue of choice of law, and the issue of jurisdiction attracted significantly less attention than choice of law in the commentary. At the same time, it was evidently rare for the parties to include forum selection provisions in their contracts, although early cases reveal examples. ${ }^{1}$ The substantial increase in the volume of crossborder transactions has led to far more disputes about jurisdiction. At the same time, express dispute resolution terms have become common in cross-border agreements, involving non-

In this chapter, references to the national reports are to the names of the authors of the national reports, e.g. references to the Australian national reports are to "Marshall (2020)".

$1 \quad$ E.g. Gienarv Meyer (1796) 2 H Bl 603. 
commercial as well as commercial parties. Both of these factors have led to a sudden development in the law about the effect of choice of court agreements, to the point that the volume of recent laws and commentary about choice of court agreements substantially eclipses that in relation to choice of law agreements. ${ }^{2}$

International instruments have been influential in the development of regional and national laws. The United Nations Convention on the Recognition and Enforcement of Foreign Arbitral Awards (the New York Convention), concluded in $1958,{ }^{3}$ has influenced the development of the law relating to choice of court agreements in various ways. This influence is most clearly evident in the Hague Choice of Court Agreements Convention 2005 ("Hague Choice of Court Convention"), ${ }^{4}$ which was inspired by and modelled on the New York Convention. ${ }^{5}$ In turn, the Hague Choice of Court Convention influenced the 2012 revision of the Brussels I Regulation, ${ }^{6}$ so the New York Convention has been indirectly influential in that sense. While the influence of the New York Convention is also clear in some countries' national laws, ${ }^{7}$ where exclusive choice of court agreements are analogised to arbitration agreements, ${ }^{8}$ in others, it evidently has had little impact. ${ }^{9}$ In many legal systems, there have been important recent changes to the law concerning choice of court agreements. Many countries have recently amended or introduced new legislation on civil procedure $^{10}$ and private international law, and regional and international instruments have had a

2 The main exceptions to this are the Regulation (EC) No 593/2008 of the European Parliament and of the Council of 17 June 2008 on the law applicable to contractual obligations OJ L 177 ("Rome I Regulation"), and the Hague Principles on Choice of Law in International Commercial Contracts 2015, each of which has generated scholarly commentary: see, e.g. (2017) 22 issue 2 Uniform Law Review, a special issue devoted to the Hague Principles. 3 United Nations Convention on the Recognition and Enforcement of Foreign Arbitral Awards 1958, entered into force 7 June 1959 ("New York Convention").

4 Convention of 30 June 2005 on Choice of Court Agreements 2005, entered into force 1 October 2015.

Hartley and Dogauchi (2005), p 791, para 1; Hartley (2013), p 19, para 1.47. The Council Proposal for a Regulation of the European Parliament and of the Council on jurisdiction and the recognition
and enforcement of judgments in civil and commercial matters (Recast) noted that "granting priority to the chosen court to decide on its jurisdiction... would largely accord with the system established in the 2005 Hague Choice of Court Agreements Convention, thus ensuring a coherent approach within the Union and at international level were the Union to decide to conclude the 2005 Convention in the future." (Brussels, 14.12.2010 COM(2010) 748 final 2010/0383/COD, pp 5, 9). See likewise, Council Decision of 4 December 2014 on the approval, on behalf of the European Union, of the Hague Convention of 30 June 2005 on Choice of Court Agreements (2014/887/EU, OJ L 353/5 10.12.2014), which states in recital (5) that "[w]ith the adoption of Regulation (EU) No 1215/2012 the Union paved the way for the approval of the Convention, on behalf of the Union, by ensuring coherence between the rules of the Union on the choice of court in civil and commercial matters and the rules of the Convention."

Oprea (2020), Section 1.1.3.

$8 \quad$ In South Africa, until recently, "South African courts treated foreign arbitration agreements in the same way as exclusive foreign choice of court agreements": Schoeman (2020), Section 4, text to note 62. The situation is similar in Taiwan: Chen (2020), Section 1.3.2. In Australia, arbitration agreements and exclusive choice of court agreements are treated as "legally cognate" (Marshall (2020), text to note 45, citing Global Partners Fund Ltd v Babcock \& Brown Ltd (in liquidation) [2010] NSWCA 196, para 60.

$9 \quad$ This includes in Greece (Panopoulos (2020), Section 1.2); Germany (Weller (2020), Section 1.2); and the People's Republic of China (Tu and Huang (2020), Section 2 (text following note 35).

10 For example, in Japan, amendments to the Code of Civil Procedure dealing with international jurisdiction, including choice of court agreements, came into effect April 2012; in Switzerland, the Code of Civil Procedure was enacted in 2011. The Brussels I Recast came into effect in 2015. 
significant effect. ${ }^{11}$ Within Europe, the 2012 recast of the Brussels I Regulation, ${ }^{12}$ which gave greater protection to exclusive choice of court agreements, influenced reform to national laws in some member states. ${ }^{13}$ The European legislation also has had some influence further afield, including in Japan. ${ }^{14}$

The growth in importance of choice of court agreements in practice has also seen a substantial increase in the commentary devoted to the effect of these agreements. This commentary is dominated by consideration of the legal effects of exclusive choice of court agreements, which are also referred to as exclusive jurisdiction clauses, ${ }^{15}$ exclusive or mandatory forum selection clauses, and obligatory or binding choice of court agreements.

In comparison to the amount of attention devoted to exclusive choice of court agreements, optional choice of court agreements (also referred to as non-exclusive jurisdiction clauses (sometimes abbreviated as "NEJ clauses"), non-exclusive choice of court or forum selection clauses, permissive forum selection clauses, and "imperfect" choice of court agreements) have been relatively neglected both by law-makers and in the commentary. ${ }^{16}$ While some reporters note that optional choice of court agreements are often included in contracts, ${ }^{17}$ others remark that there are few ${ }^{18}$ cases concerning the effect of optional agreements.

The contributions to this collection show that in some countries, the law in relation to optional choice of court agreements is undeveloped, particularly in comparison to the attention that has been given to exclusive choice of court agreements. In others, the case law is quite sophisticated. The national reports also identify a number of unresolved issues with the effect of optional choice of court agreements, and others where the law is unclear or the cases are conflicting. This collection contributes to the literature on choice of court agreements in calling attention to the

11 Article 23 of the Brussels I Regulation "partially inspired" the Belgian Private International Law Act in relation to the effect of choice of court agreements: Van Calster and Poesen (2020), Section 2.1.

12 Regulation (EU) No 1215/2012 of the European Parliament and of the Council of 12 December 2012, OJ 1 351/1 ("Brussels I Recast").

13 The Brussels I Recast influenced the Romanian Civil Code: Oprea (2020), Section 1.1.3. On the other hand, these instruments did not influence German law: Weller (2020), Section 1.2.

14 This influence relates to the introduction of special rules for consumer contracts and individual employment relations. The Japanese rules in this respect are not identical to those found in the Brussels I Recast. Chen reports that the Hague Choice of Court Convention and the EU instruments "are highly valued and referred to by Taiwanese courts in some cases": (2020), Section 1.3.3.

15 This is the term used in England and in some common law jurisdictions, including Australia and Singapore. 16 Yeo (2005), pp 307-8. At the time of writing this chapter in September 2018, there were no books written in English devoted solely to optional choice of court agreements. There are a number of books, in English as well as in other languages, which deal only with choice of court agreements, but these address optional choice of court agreements in passing and focus on exclusive choice of court agreements: e.g. Hartley (2013); Joseph (2015).

$17 \quad$ Van Calster and Poesen (2020), Section 5.

18 France (Mailhé (2020), text to note 7). 
importance of optional choice of court agreements, and the need for further research and legal development on this topic.

Much of the law and literature on choice of court agreements assumes that the agreement whether optional or exclusive - nominates the courts of a single country. However, some choice of court agreements are more complex than this. In particular, the controversial decision of the French Cour de Cassation in the Madame Xv Société Banque Privé Edmond de Rothschild ${ }^{19}$ has drawn attention to asymmetric choice of court agreements. This refers to choice of court agreements containing both exclusive and optional components. This collection also considers the effect of such agreements internationally.

\subsection{Scope of this Project}

The national reports in this collection include a number of countries which are Member States of the European Union. ${ }^{20}$ In those countries, there are several legal sources which determine the effect of choice of court agreements. These include the Hague Choice of Court Agreements Convention 2005, which at the time of writing applies in Mexico, Montenegro, and Singapore as well as the European Union. Singapore is represented in this collection. ${ }^{21}$ In those countries which are Member States of the European Union, the Lugano II Convention ${ }^{22}$ applies; as it does also in Denmark, Iceland, Norway and Switzerland. Switzerland is represented in this collection. ${ }^{23}$ In the European Union Member States, the law on jurisdiction is dominated by the Brussels I Recast, which applies to any choice of court agreement not covered by the Hague Convention that designates the courts of a Member State. Residual national laws apply to choice of court agreements that are not covered by the Hague Convention, the Lugano II Convention, or the Brussels I Recast. In the other countries represented in this collection, the relevant laws are national laws, which are sometimes determined at the provincial level, as is the case in Canada. ${ }^{24}$

19 Cass civ, 1ère, 26 September 2012. This case and a number of subsequent decisions of the French Cour de Cassation are discussed in detail by Mailhé (2020), Section 3.

20 At the time this collection was written, in 2018, the UK was still a member state of the European Union, and the national report for the UK reflects this.

$21 \quad$ Chong (2020).

22 Convention on jurisdiction and the recognition and enforcement of judgments in civil and commercial matters, OJ L 339, 21.12.2007, entry into force 01/01/2010 (“Lugano II Convention").

$23 \quad$ Haas and MacCabe (2020).

24 The Canadian civil law and common law are both covered in this collection: Guillemard and Sabourin (2020); Saumier (2020). 


\section{Attitudes to Jurisdictional Agreements}

In general, the legal response to choice of court agreements has changed over time. The national reports demonstrate that, for most legal systems, much of this development has been recent, and much of it has brought about quite radical changes.

Attitudes to agreements about forum tend to cluster at opposite ends of the spectrum: at one end, they are regarded as being superior to other means of allocating jurisdiction, at least in international commercial disputes. At the other end of the spectrum, they are derided as being unacceptable as either inconsistent with, or undermining, public interests in the regulation of litigation. Historically, the latter position prevailed in many legal systems. For example, in the US and in Québec, choice of court agreements were invalid as contrary to public policy. ${ }^{25}$ But there are some important exceptions. Mailhé notes that party autonomy was regarded by the drafters of the French Civil Code, in 1804, as "a natural exception to the rules they proposed in its articles 14 and 15" ${ }^{26}$ In the German Code of Civil Procedure, which entered into force in 1879, "choice of court agreements could be agreed upon without any major limitations." ${ }^{27}$ In Taiwan, the Code of Civil Procedure has allowed the parties to designate a court to exercise jurisdiction from the time of its promulgation in $1930 .^{28}$

More recently, the former view that choice of court agreements are desirable and should be respected has become popular. For example, Saumier writes that "[t]he attitude toward choice of court agreements in Canadian common law provinces is very positive"; ${ }^{29}$ the other reports express similar sentiments. ${ }^{30}$ In most legal systems, the law now enables the parties to choose the forum for the resolution of disputes.

In a few countries, the laws reveal historical, ongoing, and some new, hesitations about completely accepting party autonomy. Again the German national law is an exception to the general trend; in 1974, the law relating to choice of court agreements was fundamentally reformed, and significant

\footnotetext{
25 Buxbaum (2020), Section 2; Guillemard and Sabourin (2020), Section 1, text to notes 30-32. See similarly, Tarman and Oba, referring to cases from the Turkish Cour de cassation, which establish that "a refusal of jurisdiction by the Turkish courts due to a jurisdiction agreement would indicate a mistrust of the adjudication of Turkish courts and would be contrary to public order": (2020), Section 3.3 (text to note 31).

$26 \quad$ Mailhé (2020), Section 1.

$27 \quad$ Weller (2020), Section 1.1, text to note 3, citing the Zivilprozessordnung, section 38.

$28 \quad$ Chen (2020), Section 1.2.1.

29 Saumier (2020), Section 1.

30 Buxbaum states that "[i]n the vast majority of US states, choice of court agreements, both optional and exclusive, are viewed with approval.”: (2020), Section 3.1. See similarly Belgium (Van Calster and Poesen (2020), Section 2.1); Romania (Oprea (2020), Section 1.1.3); and South Africa (Schoeman (2020), Section 3.3, text to notes 34 and 35).
} 
limitations on the parties' freedom were imposed, ${ }^{31}$ which remain in force. ${ }^{32}$ Several US states also "maintain the traditional hostility to choice of court agreements." 33 As explained below, the law in many countries now recognises that choice of court agreements involving presumptively weaker parties require different regulation to those involving commercial parties. ${ }^{34}$

\section{The Distinction between Exclusive and Optional Choice of Court}

\section{Agreements}

The distinction between exclusive and optional choice of court agreements is very well established in some legal systems. In others, particularly those in which the parties' ability to choose their forum has only recently been accepted, the distinction is less well established. For example, in China "The concept of non-exclusive choice of court agreement... was first formally presented in the 2005 [Supreme People's Court] Summary".35 In the Netherlands, all choice of court agreements are "commonly referred to as 'forumkeuze' (i.e. 'choice of forum')". ${ }^{36}$ In South Africa, there is no reference in national law to optional choice of court agreements; ${ }^{37}$ and "no clear distinction is drawn between exclusive and optional choice of court agreements". ${ }^{38}$ Several reporters note that their national legislation makes no reference to optional choice of court agreements, and that there is very little relevant case law. ${ }^{39}$

A preliminary issue is identifying the applicable law to determine whether a choice of court is exclusive or optional. There is a diversity of views on this question. In some countries, it is well settled that this is determined by the governing law of the contract as a whole ${ }^{40}$ or the governing

\footnotetext{
31 Weller (2020), Section 1.1, text to note 9, citing the Law to Change the Code of Civil Procedure of 21 March 1974, Federal Law Gazette, BGBl 1974 I 753, which came into effect on 1 April 1974.

$32 \quad$ Weller (2020), Section 1.1, text to note 10.

33 Buxbaum (2020), Section 3.1.

$34 \quad$ See below, Section 8.

35 Tu and Huang (2020), Section 2 (text to note 27).

36 Rammeloo (2020), Section 1.1. Likewise, in Québec, the Civil Code does not distinguish between exclusive and optional choice of court agreements: Guillemard and Sabourin (2020), Section 2.2.1.

37 This is the case in South Africa: Schoeman (2020), Section 3, text to note 26.

$38 \quad$ Schoeman (2020), Section 6.

39 E.g. France (Mailhé (2020), text to note 7).

40 This is so in South Africa (Schoeman (2020), Section 3.1). The position may be different in China (Tu and Huang (2020), Section 3, text to note 42). In England, it is presumed that the applicable law for the choice of court agreement is the same as the applicable law for the contract as a whole: Merrett and Carruthers (2020), Section 2.1.1 (citing Mauritius Commercial Bank v Hestia [2013] EWHC 1328 (Comm)). In Shandong Jufeng Network v MGame \& Tianjin Fengyun Network, the Supreme People's Court of China "held that the choice of law agreement and the choice of court agreement are two separate legal acts and therefore different applicable laws should be applied to regulate them.": (2009) Min San Zhong Zi No 4; Model Case No 44, Notice of the Supreme People's Court on Issuing 10 Major Cases and 50 Model Cases on China's Judicial Protection of the Intellectual Property Rights in 2009 [2010] Fa No 172, promulgated on 14 April 2010, cited in Tu and Huang (2020), Section 3, text to note 46.
} 
law of the choice of court agreement, if that were different. ${ }^{41}$ However, even where that is the case, the courts sometimes simply state that a choice of court agreement is exclusive or optional without justifying that conclusion. ${ }^{42}$

It seems to be quite common that courts do not refer to any choice of law analysis when determining whether a choice of court agreement is exclusive or optional. ${ }^{43}$ One problem with undertaking a choice of law analysis is that it might lead to practical difficulties, given a lack of clarity under some national laws as to the distinction between exclusive and optional choice of court agreements. ${ }^{44}$ Takahashi proposes that a clear test for distinguishing exclusive from optional choice of court agreements should be developed, and that it should be applied as an overriding mandatory rule - that is, irrespective of the otherwise applicable law. ${ }^{45}$

The presumption in favour of exclusivity in the Hague Choice of Court Agreements Convention might be applied either by the nominated court, to determine whether the choice of court is exclusive within the terms of the Convention, or by a non-chosen court which has been seised and which is determining whether it is obliged to suspend or dismiss those proceedings because of an exclusive choice of court agreement in favour of the courts of another contracting state. ${ }^{46}$ When the nominated court is determining the issue, the application of the presumption should not be justified on the basis of the Hague Convention being part of the law of the exclusively chosen court, because the issue as to whether it is the exclusively chosen court has not yet been determined. That would mean that the chosen court could only be applying the presumption under the Convention on the basis that the Convention is part of the law of the forum. If the law of the forum was the governing law of the choice of court agreement, that would not be objectionable. But if the governing law of the choice of court agreement was the law of another country which was not a contracting state to the Convention, any reference to the Convention would have to be justified on the basis that the Convention was applicable as part of the law of the forum per se. As Chong points out in the context of the Singaporean legislation which gives effect to the Convention, ${ }^{47}$ this might be justified on the basis that the Convention establishes a

\footnotetext{
$41 \quad$ Merrett and Carruthers (2020), Section 2.1.1, note 20 (citing Collins (2012), para 12-105 and Maher and Rodger (2010), para 17-17); Chong (2020), Section 2.2.

42 This is so, for example, in South Africa: Schoeman (2020), Section 3.1.

43 This is so in common law Canada (Saumier (2020), Section 2); France (Mailhé (2020), Section 1.1); Japan (Takahashi (2020), text to note 13); the Netherlands (Rammeloo (2020), Section 2.2).

$44 \quad$ Takahashi (2020), text following note 22.

$45 \quad$ Takahashi (2020), Section 4.

$46 \quad$ Hague Choice of Court Agreements Convention, Article 6.

47 Supreme Court of Judicature Act Cap 322, Rev Ed 2007, section 18F which relevantly provides that "if there is no express provision to the contrary" in the choice of court agreement, then "an agreement to submit to the jurisdiction of the Singapore International Commercial Court shall be considered to have agreed - (a) to submit to
} 
forum mandatory rule. ${ }^{48}$ The same reasoning might apply to the Brussels I Recast and the Lugano II Convention, although it has been suggested that the characterisation of the agreement as optional or exclusive should be governed by the law of the chosen court. ${ }^{49}$ Of course, this presents insuperable difficulties if the choice of court agreement nominates the courts of more than one country. ${ }^{50}$

As just noted, another possibility is that the law of the forum should be applied to determine whether a choice of court agreement is exclusive or optional. ${ }^{11}$ The law of Québec is applied to this question, either because the issue is one of characterisation, ${ }^{52}$ or one of procedure. ${ }^{53}$ In the Czech Republic, forum law applies because the "procedural character" of choice of court agreements, and because the "emphasis on the transfer of jurisdiction continues to prevail." 54

In some countries, there are conflicting authorities as to the choice of law rule which should be applied to determine whether a choice of court agreement is optional or exclusive. For example, whereas a majority of Chinese courts take the view that this is a procedural question which should be determined according to the law of the forum, ${ }^{55}$ a minority of Chinese courts insist that the governing law of the main contract should be applied to interpret the choice of court agreement. ${ }^{56}$

\subsection{Distinguishing an exclusive from an optional choice of court agreement}

There are a number of techniques used to determine whether a particular choice of court agreement is exclusive or optional. The simplest is that used in the Hague Choice of Court Agreement Convention, which defines an exclusive choice of court agreement, ${ }^{57}$ but also deems that a choice of court agreement is exclusive "unless the parties have agreed otherwise". ${ }^{8}$ The solution of deeming a choice of court agreement to be exclusive was adopted in the Brussels I Recast, ${ }^{59}$ and in the Lugano II Convention on Jurisdiction and the Enforcement of Judgments in

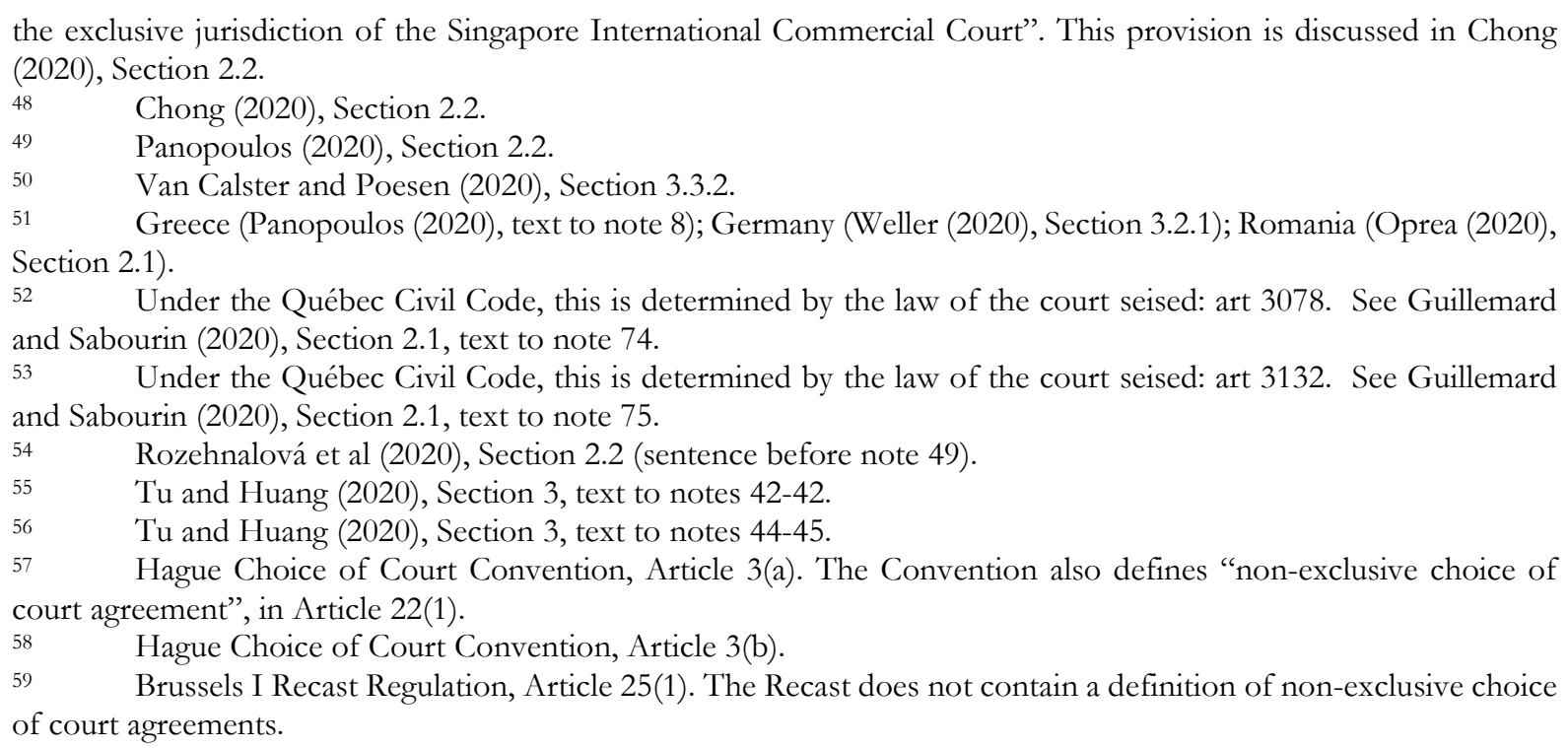


Civil and Commercial Matters. ${ }^{60}$ This does not appear to have influenced the national law of most of the EU Member States, for situations falling outside the scope of the Recast, although the Romanian Civil Procedure Code provides that in the absence of contrary stipulation, the jurisdiction agreement is exclusive. ${ }^{61}$ The same presumption is found in other countries including Greece $^{62}$ and Switzerland. ${ }^{63}$ In the Czech Republic, it is generally assumed that choice of court agreements are exclusive, although there is no explicit presumption to that effect. ${ }^{64}$ A suggestion made in Japan in the preparation of the reforms to the Code of Civil Procedure that foreign choice of court agreements should be deemed to be exclusive was rejected "as being contrary to international business practice", and the issue was left to interpretation of individual agreements. ${ }^{65}$ Rather ironically, there is a tendency in Japan to characterise choice of court agreements as being exclusive. $^{66}$

Under the national law of most countries, there is no explicit presumption of exclusivity. ${ }^{67}$ Rather, the distinction between exclusive and optional choice of court agreements is one of interpretation of the agreement; ${ }^{68}$ determining whether a choice of court agreement is optional or exclusive is a question of the parties' intentions. ${ }^{69}$ In some countries, the courts tend to find that agreements are exclusive. ${ }^{70}$ Attempting to identify the parties' intentions is often very difficult, and several reporters note that decisions are inconsistent. ${ }^{71}$

In common law countries, the test of whether a choice of court agreement is exclusive is whether the parties promised to commence or pursue proceedings, if at all, only in the courts of a single legal system. ${ }^{72}$ This clearly demonstrates the contractual nature of choice of court agreements in the common law. In most countries, the courts consider a range of different factors in determining

\footnotetext{
60 Lugano II Convention, Article 23. This Convention does not contain a definition of non-exclusive choice of court agreements.

61 Oprea (2020), note 42, citing the Romanian Civil Procedure Code, article 1068(1).

62 Greek Code of Civil Procedure, Art 44.

63 Swiss Code on Civil Procedure, Article 17(1); Swiss Private International Law Act, Article 5(1); Haas and MacCabe (2020), Section 5, text to note 53.

$64 \quad$ Rozehnalová et al (2020), Sections 2.2.1, 2.8.

65 Takahashi (2020), Section 2.3, text to note 12.

66 Takahashi (2020), Section 2.3.

67 This includes Germany: Weller (2020), Section 1.2. The Scottish law is based on the Brussels Convention, and therefore does not include a presumption of exclusivity: Merrett and Carruthers (2020), Section 1.1.

68 Netherlands (Rammeloo (2020), Section 2.3); Taiwan (Chen, (2020) Section 2.2.2).

69 Including China (Tu and Huang (2020), Section 3, text to note 48; although they also note that some courts, including the Supreme People's Court, have implicitly and explicitly adopted a presumption of exclusivity in some cases) and Taiwan (Chen (2020), Section 2.2.2).

70 This is so in the Czech Republic (Rozehnalová et al (2020), Section 2.1) and Japan (Takahashi (2020), Section 2.3), for example.

$71 \quad$ For China, see Tu and Huang (2020), Section 3, text to and following note 51.

72 E.g. BNP Paribas SA v Anchorage Capital Europe LLP [2013] EWHC 3073 (Comm), para 87 and 88, cited by Merrett and Carruthers (2020), Section 2.2.1, text to note 47.
} 
whether the choice of court agreement is exclusive. However, some reporters state that the cases have not articulated any principles of interpretation. ${ }^{73}$

In some jurisdictions, the courts apply a presumption against exclusivity; this is so in some US states ${ }^{74}$ and in Taiwan. ${ }^{75}$

In addition to the possibility that the courts of a single country may take different approaches and reach apparently inconsistent conclusions in different cases as to the character of choice of court agreements, the same agreement may be interpreted as being non-exclusive in one country, and as exclusive in another. For example, in Compania Sud Americana de Vapores $S A v$ Hin-Pro International Logistics Ltd, the choice of court agreement in favour of the English courts was held to be nonexclusive by the Chinese courts, ${ }^{76}$ and exclusive by the English courts. ${ }^{77}$ In another case, a choice of court agreement which nominated Australian courts was interpreted by a US court as nonexclusive, but would have been interpreted by the Australian court as exclusive. ${ }^{78}$ This suggests that courts may be inclined to interpret an ambiguous choice of court agreement as exclusive, if it nominates the forum court, and as optional, if it nominates a foreign court. ${ }^{79}$

\subsection{Varieties of choice of court agreements}

Choice of court agreements can take many different forms, and their effect will depend in every case on what the agreement actually provides. Referring to the clause in Sabah Shipyard (Pakistan) Ltd v Islamic Republic Of Pakistan, ${ }^{80}$ which the English Court of Appeal described as non-exclusive, Briggs argued that "[i]t denatures such a clause to call it non-exclusive, for it was more subtle, more complex, than that." ${ }^{81}$ Briggs has argued that the distinction between exclusive and non-exclusive choice of court agreements is "unhelpful”, because some choice of court agreements do not neatly fall into one or the other category. ${ }^{82}$ In particular, while there appears to be widespread agreement about what constitutes an exclusive choice of court agreement, ${ }^{83}$ the concept of optional choice

\footnotetext{
73 E.g. Takahashi (2020), Section 2.3.

$74 \quad$ Buxbaum (2020), Section 4.

$75 \quad$ Chen (2020), Section 2.2.2.

76 Zheijiang High People's Court, (2013) Zhe Xia Zhong Zi No 42, cited by Tu and Huang (2020), Section 3, note 52 .

77 [2015] EWCA 401 (Civ).

78 Armacel Pty Ltd v Smurfit Stone Container Corporation [2008] FCA 592. In this case, the Australian court held that because of the US judgment, the plaintiff "was barred by an issue estoppel from contending that [the clause] was an exclusive jurisdiction clause": para 66 and 90.

79 See likewise Tang, Xiao and Huo (2016), p 65.

80 [2003] 2 Lloyd's Rep 571.

$81 \quad$ Briggs (2008), p 118, para 4.21.

82 Briggs (2012), p 118, para 4.21. See, likewise, Collins (2012), para 12-102.

83 Although it is possible that the parties can include what Merrett and Carruthers refer to as an "exclusively non-exclusive" choice of court agreement, which nominates the courts of one country as having exclusive jurisdiction if one party is claimant, and the courts of another country as having exclusive jurisdiction if the other party is claimant:
} 
of court agreement is often defined by reference to what it is not (i.e. purely exclusive), and many different types of choice of court agreement satisfy that criterion. ${ }^{84}$

The Explanatory Report to the Hague Convention on Choice of Court Agreements gives some examples of non-exclusive choice of court agreements (i.e. agreements which do not come within the Convention definition of exclusive choice of court agreements). These include agreements that impose "no restrictions on the courts before which proceedings may be brought", giving as an example a clause which nominates the courts of one country but also states that "this shall not preclude the bringing of proceedings in any other court that has jurisdiction under the law of the State in which it is located." 85 This is contrasted with non-exclusive agreements "with limitation"; the example given is "an agreement that designates a court or the courts of two or more Contracting States to the exclusion of all others". ${ }^{86}$ In Belgium, "scholarship distinguishes two kinds of optional choice of court agreements", namely "non-exclusive" choice of court agreements (which confer non-exclusive jurisdiction on one or more courts), and "complex" choice of court agreements (which confer jurisdiction on multiple courts, "specifying that the parties can commence proceedings in one of these courts to the exclusion of the courts which would ordinarily have jurisdiction." ${ }^{87}$ Oprea identifies four different types of non-exclusive choice of court agreements: simple non-exclusive choice of court agreements, hybrid choice of court agreements, multiple choice of court agreements, ${ }^{88}$ and asymmetric choice of court agreements. ${ }^{89}$

\section{The Positive Effects of Choice of Court Agreements}

Choice of court agreements are relevant at two different stages in a cross-border dispute. This is conventionally addressed in terms of their "positive" and "negative" effects. The first stage relates to establishing whether a chosen court is competent to hear and determine a dispute. This is referred to as prorogation, the "jurisdiction-granting" effect, ${ }^{90}$ submission to the jurisdiction, or the positive effect of a choice of court agreement. Whether an agreement has the effect of establishing the jurisdiction of a court chosen by the parties depends on the procedural law of the forum court and whether it recognises the parties' agreement as a basis of competency. Almost all

(2020), Section 2.2.1, text to note 38. The choice of court agreement in Meeth v Glacetal Case 23/78 [1978] ECR 2133 was of this kind. See also Keyes and Marshall (2015), pp 357-8.

$84 \quad$ See also Oprea (2020), Section 2.6; Noble Power Investments Ltd v Nissei Stomach Tokyo Co Ltd [2008] 5 HKLRD 631, para 24.

$85 \quad$ Hartley and Dogauchi (2005) p 845, para 246.

$86 \quad$ Hartley and Dogauchi (2005) p 845, para 247 (emphasis original).

$87 \quad$ Van Calster and Poesen (2020), Section 3.1.

$88 \quad$ Oprea (2020), Section 1.2.

89 Oprea (2020), Section 2.6, text to notes 36-38.

$90 \quad$ Hartley (2013), p 5, para 1.08. 
legal systems now recognise the positive effect of choice of court agreements. ${ }^{91}$ The Brussels I Recast, for example, provides in Article 25(1) that

"If the parties, regardless of their domicile, have agreed that a court or the courts of a Member State are to have jurisdiction to settle any disputes which have arisen or which may arise in connection with a particular legal relationship, that court or those courts shall have jurisdiction, unless the agreement is null and void as to its substantive validity under the law of that Member State (emphasis added)."

In some countries, the nominated court is obliged to accept the submission to jurisdiction. ${ }^{92}$

However, in a few countries, the parties' agreement is not sufficient; there must be another basis of jurisdiction. ${ }^{93}$ At common law, a choice of court agreement in favour of the forum is not itself a separate basis of jurisdiction because jurisdictional competence depends on service. ${ }^{94}$ This has been cured by legislation which authorises service out of the jurisdiction if the defendant submitted to the jurisdiction..$^{95}$

Most legal systems also recognise that where the defendant participates in the proceedings in the forum without contesting jurisdiction, the forum court has jurisdiction. ${ }^{96}$ In some legal systems, this is conceptualised as an implied or tacit choice of court agreement. In others, it is understood and described as a unilateral submission to the jurisdiction by the defendant, which is normally analysed in terms of a waiver of the defendant's right to object to the court's jurisdiction.

In quite a few countries, the law has only recently accepted the parties' ability to prorogate jurisdiction. For example, in the Netherlands, this was only accepted by the Dutch Hoge Raad (Supreme Court) in $1985 .{ }^{97}$ In China, the parties' ability to contract for jurisdiction was not recognised until $1991 .^{98}$ Romanian law explicitly recognised the effectiveness of choice of court

91 E.g. Brussels I Recast Regulation, Article 25(1); Lugano II Convention, Article 23(1); Greece (Greek Code of Civil Procedure, Arts 42-44); Québec (Civil Code of Québec, article 3148(4)); Singapore (Astrata (Singapore) Pte Ltd $v$ Portcullis Escrow Pte Ltd [2011] 3 SLR 386); Switzerland (Swiss Code on Civil Procedure, Article 17), and the UK (Merrett and Carruthers (2020), Section 1.1).

92 Including the Czech Republic (Rozehnalová et al (2020), Section 1.3) and Switzerland (Haas and MacCabe (2020), Section 6.1 (citing the Swiss Code on Civil Procedure, Article 17, and the Lugano II Convention, Article 23)).

93 This is the case in South Africa (Schoeman (2020), Section 3.5) and in some US states (Buxbaum (2020), text to note 76 , referring in particular to Florida).

$94 \quad$ Keyes (2015), p 225.

$95 \quad$ Marshall (2020), Section 2.3.1.1.

96 Brussels I Recast Regulation, Article 26(1); Lugano II Convention, Article 24(1); Greek Code of Civil Procedure, Art 42 S 2; Japanese Code of Civil Procedure, Article 3-8; Taiwanese Code of Civil Procedure, Article 25. $97 \quad$ Piscator, HR February 1, 1985, NJ 1985, 698 (discussed by Rammeloo (2020), Sections 1.1 and 2.5).

981991 Chinese Civil Procedure Law, Articles 25 and 224 (promulgated and entered into force on 9 April 1991). These provisions were replaced by Article 34 of the 2012 Chinese Civil Procedure Law (which was in turn replaced by Article 34 of the 2017 Chinese Civil Procedure Law). See Tu and Huang (2020), Section 2, text to notes 13-16. 
agreements for the first time in the Romanian Civil Procedure Code which came into effect in $2013 .{ }^{99}$

The reason that the positive effect of choice of court agreements was, historically, controversial, is that the assumption of jurisdiction in cross-border cases was justified as an aspect of sovereignty, and the parties' ability to invoke the courts' jurisdiction was inconsistent with territorial limitations on the exercise of sovereignty. This is reflected, for example, in the Dutch "traditional doctrine of sovereignty according to which jurisdiction could be attributed to courts by the law only (i.e. not by the autonomous will of the contracting parties)."100

Where the relevant procedural law permits prorogation, this basis of jurisdiction contrasts with the other rules establishing the courts' jurisdiction, which rely on factual connections between the forum and the parties, such as personal connections of domicile, or connections between an aspect of the dispute and the forum, such as that the contract in dispute was to be performed in the territory of the forum court. The lack of a requirement of factual connection to the chosen court was one reason for concerns about the legitimacy of prorogation as a basis of jurisdictional competency; whereas, from the perspective of parties from different legal systems, a lack of factual connection might be desirable because it would indicate that the chosen courts would be neutral as between the parties to the contract.

There is little difference between optional and exclusive choice of court agreements in terms of their positive effect. ${ }^{101}$

\subsection{The problem with prorogation}

Most courts now take a favourable attitude to choice of court agreements which nominate them. Nygh suggested that "For the prorogated forum the choice of the parties presents no challenge to State authority. Concepts of territorial sovereignty and control are not offended, but rather flattered, when foreigners submit to the jurisdiction." ${ }^{102}$ Given the current popular view of international litigation as a product, it is hardly surprising that most legal systems welcome the parties' contractual choice of the forum. However, this fails to recognise the effect of the prorogation in potentially exacerbating, or creating, a problem of overlapping jurisdictions.

In the legal systems which allow prorogation without any requirement of connection, where the prorogation is the only basis on which a nominated court is competent, the choice of court

\footnotetext{
$99 \quad$ Oprea (2020), Section 1.1.3, text to notes 14-15.

100 Rammeloo (2020), Section 1.1, text to note 1.

$101 \quad$ Chen (2020), Section 2.1.

$102 \quad$ Nygh (1999), p 15.
} 
agreement has the effect of increasing the number of competent courts in which either party could bring proceedings. If the courts of more than one legal system would have regarded themselves as competent irrespective of the agreement, prorogation exacerbates the problem of overlapping jurisdictions, by making one more court competent. If there would have only been one competent court but for the parties' choice of court agreement (admittedly an unlikely scenario, in a crossborder dispute), prorogation creates the problem of overlapping jurisdictions. If a nominated court is otherwise competent under its other rules of jurisdictional competency, the prorogation neither creates nor adds to the competency of that court, and does not exacerbate the problem of overlapping jurisdictions, which would arise in any case.

\section{The Negative Effects of Choice of Court Agreements}

The second stage at which a choice of court agreement is relevant relates to its effect in controlling the possibility or the reality of parallel proceedings. At this stage, a choice of court agreement might be challenged in either the chosen, or non-chosen, courts. It will not necessarily be given the same effect in the chosen and the non-chosen courts, including because the chosen court will, as Nygh observed, be flattered by the choice, whereas the non-chosen courts may be offended, especially if the factual connections to the non-chosen court are strong. ${ }^{103}$ This may be true of optional choice of court agreements as well as of exclusive choice of court agreements.

The legal effects of choice of court agreements are regarded as a matter of procedure and for that reason subject to forum law. ${ }^{104}$

The following sections first address the negative effects of exclusive choice of court agreements; and then the negative effects of optional choice of court agreements.

\subsection{The negative effect of exclusive choice of court agreements}

Much of the law and scholarship about choice of court agreements concerns the effect of exclusive agreements in non-chosen courts. ${ }^{105}$ In this context, choice of court agreements are often said to have a negative, derogative, or "jurisdiction-depriving" 106 effect on a non-chosen court which is competent, under its own rules of jurisdiction, to hear the dispute. This only necessarily follows if the choice of court agreement is exclusive, because at least in most types of optional choice of

\footnotetext{
$103 \quad$ Nygh (1999), pp 15, 19.

104 This is so in England and Scotland (Merrett and Carruthers (2020), Section 2.3); Germany (Weller (2020), Section 3.3); Japan (Takahashi (2020), Section 2.1); Singapore (Chong (2020), Section 2.2); Taiwan (Chen, (2020), Section 2.3.1); the US (Buxbaum (2020), Section 6.1).

105 Saumier (2020), Section 3.1.

$106 \quad$ Hartley (2013) p 5, para 1.08.
} 
court agreements, the parties do not by their agreement foreclose the possibility of litigating in courts other than those nominated in the choice of court agreement. An exclusive choice of court agreement only has a jurisdiction-depriving effect if the non-chosen court is obliged to enforce an exclusive choice of court agreement by staying its proceedings. ${ }^{107}$ The Hague Choice of Court Convention, ${ }^{108}$ the Brussels I Recast, and the national laws of some countries ${ }^{109}$ require the nonchosen courts of the forum to stay proceedings where the parties have agreed to the exclusive jurisdiction of a foreign court.

The Brussels I Recast exemplifies this approach to the strict enforcement of exclusive choice of court agreements. Article 31(2) states

"Without prejudice to Article 26, where a court of a Member State on which an agreement as referred to in Article 25 confers exclusive jurisdiction is seised, any court of another Member State shall stay the proceedings until such time as the court seised on the basis of the agreement declares that it has no jurisdiction under the agreement." (emphasis added)

Article 31(3) further states that "Where the court designated in the agreement has established jurisdiction in accordance with the agreement, any court of another Member State shall decline jurisdiction in favour of that court." The introduction of article 31 is one of the most important recent developments in private international law. The Lugano II Convention has not been amended to incorporate a similar protection of exclusive choice of court agreements.

The common law approach is different in principle. The line of English cases commencing with The Eleftheria ${ }^{110}$ have been very influential in England, and most common law countries apply the principle from that case that exclusive choice of court agreements, whether in favour of the forum or of a foreign court, should be enforced unless there are strong reasons for non-enforcement. ${ }^{111}$ Clearly, this gives the non-chosen court a discretion whether to enforce the agreement.

Relatively speaking, the effect of an exclusive choice of court agreement which is being challenged in proceedings in the chosen court has not been the subject of much litigation or much study.

\footnotetext{
107 Under the common law, exclusive choice of court agreements are not strictly enforceable; the courts will generally enforce them, but this is subject to the courts' discretion, and the courts may not enforce even an exclusive choice of court agreement if there are strong grounds, cause, or reasons for non-enforcement: Donohue v Armco [2001] UKHL 64 (UK House of Lords); Akai Pty Ltd v The People's Insurance Co Ltd (1996) 188 CR 418 (Australian High Court); ZI Pompey Industrie v ECU-Line NV 2003 SCC 27 (Supreme Court of Canada); Amerco Timbers Pte Ltd v Chatsworth Timber Corp Pte Ltd [1977-78] 2 SLR 112 (Singapore Court of Appeal).

108 Article 6.

109 Turkey (Tarman and Oba (2020), Section 3.3, text to note 33). Note, however, that the Turkish courts sometimes establish their jurisdiction on the basis of the principle of good faith, if the respondent is domiciled in Turkey. Tarman and Oba note that this "reasoning is heavily criticized in the academic commentary": (2020), Section 3.3.2.1, text to note 43 .

[1970] P 94.

111 E.g. Australia (Marshall (2020), Section 3); Singapore (Chong (2020), Section 3). This case has also been influential in South Africa (Schoeman (2020), Section 3.4).
} 
Nygh's comment, mentioned above, in relation to a prorogated court being flattered by being selected is also pertinent in terms of the attitude the court will have to a litigant challenging the nominated court's jurisdiction.

In the Hague Choice of Court Agreements Convention, ${ }^{112}$ the Brussels I Recast, and the national law of some countries, ${ }^{113}$ the court nominated in an exclusive choice of court agreement cannot decline jurisdiction in favour of a foreign court. The Civil Code of Québec goes even further, stating that the

"Québec authorities have no jurisdiction where the parties have chosen by agreement to submit the present or future disputes between themselves relating to a specific legal relationship to a foreign authority, or to an arbitrator". ${ }^{114}$

In other legal systems, the court nominated in an exclusive choice of court agreement has a discretion not to exercise jurisdiction. In common law systems, although an exclusive choice of court agreement should be enforced in most cases, it may not be if the party resisting its enforcement shows "strong" reasons or cause for its non-enforcement. ${ }^{115}$ The English House of Lords stayed proceedings in such a case, in Donohue v Armco Inc. ${ }^{116}$

As in the case of prorogation, the development of the law in relation to the negative effect of exclusive choice of court agreements is fairly recent in most countries. For example, before 1994, while the courts of Québec enforced choices of court in favour of the forum, they would not give effect to choice of court agreements that nominated foreign courts. ${ }^{117}$

\subsection{The negative effects of optional choice of court agreements}

Whereas the law of different legal systems has shown strong signs of convergence in relation to the positive effects of both exclusive and optional choice of court agreements, and the negative effects of exclusive choice of court agreements, there are no such indications of convergence in relation to the negative effect of optional choice of court agreements.

The negative effects of optional choice of court agreements are more complicated than the negative effects of exclusive choice of court agreements, as the national reporters attest. The

\footnotetext{
$112 \quad$ Article 5(2).

113 This is so for example in China (Tu and Huang (2020), Section 3, text to note 60); and Japan, except where the foreign court is deemed to have exclusive subject matter jurisdiction (Takahashi (2020), Section 1.1, text following note 2). Australia and New Zealand have enacted reciprocal legislation regulating jurisdiction and judgments in transTasman proceedings (the Trans-Tasman Proceedings Acts 2010). Inter alia, this legislation was designed to be consistent with the Hague Choice of Court Convention, and as a result, the courts nominated in an exclusive choice of court agreement cannot stay those proceedings: Trans-Tasman Proceedings Act 2010 (Cth) s 20(1)(b). See Marshall (2020), text to note 31 .

$114 \quad$ Art 3148.

115 Donohue v Armco Inc [2001] UKHL 64, para 24.

116 Donohue v Armco Inc [2001] UKHL 64.

117 Guillemard and Sabourin, Section 1 text to note 29 and following note 30.
} 
Hague Choice of Court Convention does not contain any direct principles in relation to the optional choice of court agreements, and the Brussels I Recast Regulation does not contain any specific principles relating to the effect of such agreements.

The Hague Choice of Court Convention does not regulate optional choice of court agreements directly, but it affects them indirectly in two ways. The first is that the Convention deems choice of court agreements to be exclusive. In some legal systems, the effect of this will be that fewer choice of court agreements will be optional, than would have otherwise been the case under national laws about the distinction between optional and exclusive choice of court agreements. ${ }^{118}$ The second is that contracting states can opt to recognise the judgments given by a court of another contracting state, the jurisdiction of which court depends on the parties' optional choice of that court. Contracting states can make a declaration under article 22, the effect of which would be that judgments rendered by the courts of other contracting states which had also made a declaration under article 22 and the jurisdiction of which derived from a non-exclusive choice of court agreement would be recognised by the contracting state making the declaration. To date, none of the contracting states has made such a declaration.

While the Recast enables prorogation of jurisdiction, and protects exclusive choice of court agreements by requiring courts other than those nominated in an exclusive choice of court agreement to stay proceedings in favour of the jurisdiction of the nominated courts, it contains no specific provisions concerning the negative effects of an optional choice of court agreement. It therefore gives no priority to optional choice of court agreements, when it comes to the allocation of jurisdiction. Rather, "substantive jurisdiction as between Member State courts will still be determined by which court is first seised", ${ }^{119}$ pursuant to Article 29.

It is not clear whether, if proceedings are commenced in the courts of a Member State which is nominated in an optional choice of court agreement (pursuant to the Recast, article 25), proceedings can be stayed under national procedural rules. ${ }^{120}$ It is also unclear whether, if proceedings are commenced in the courts of a Member State pursuant to another ground of jurisdiction, those proceedings might be stayed on the basis of an optional choice of court agreement which nominated the courts of a non-Member State. ${ }^{121}$

Under the national law of most countries, optional choice of court agreements have a different, and much weaker, effect than exclusive choice of court agreements. However, in some countries,

\footnotetext{
$118 \quad$ Marshall and Keyes (2017), p 275.

$119 \quad$ Joseph (2015), p 314, para 10.56.

$120 \quad$ Merrett and Carruthers (2020), Section 2.3.4.

$121 \quad$ Merrett and Carruthers (2020), Section 2.3.4.
} 
the forum court which is nominated in an optional choice of court agreement is obliged to exercise its jurisdiction. In China, although a version of forum non conveniens applies, the courts cannot decline jurisdiction in favour of a foreign court, if the parties nominated the Chinese courts in an optional choice of court agreement. ${ }^{122}$

The situation is similar in Japan. Article 3-9 of the Japanese Code of Civil Procedure enables a Japanese court to dismiss the proceedings

"if, taking into account the nature of the case, the burden on the defendant to answer the claim, the location of evidence and any other factors, the court finds that there are special circumstances by reason of which hearing and determining the case in Japan would impair fairness between the parties or hinder the proper and efficient conduct of proceedings",

and this clearly applies where there is an optional choice of court in favour of Japanese courts. However, Takahashi notes that "dismissal will be rare where Japanese courts are chosen by the parties because 'fairness between the parties' would usually be promoted by respecting their agreement." 123 Similarly, in Taiwan, if the parties nominated the Taiwanese courts as having jurisdiction, the court is not obliged to stay its proceedings, even if foreign proceedings were commenced first. ${ }^{124}$

The negative effects of optional choice of court agreements differ between different legal systems. This diversity was one of the reasons that optional choice of court agreements were excluded from the Hague Choice of Court Convention. The Explanatory Report to the Convention notes that if proceedings had been commenced first in a forum other than that nominated in an optional choice of court agreement, "[t]his would raise issues of lis pendens and forum non conveniens that would have been difficult to resolve in an acceptable way." ${ }^{125}$

In those legal systems which rely on lis pendens to resolve problems of overlapping jurisdictions (assuming there are no issues of exclusive subject matter jurisdiction), the main issue is the sequence in which the respective courts' jurisdiction was seised. ${ }^{126}$ In some countries, an optional choice of court agreement may be a factor to be considered but is not determinative. ${ }^{127}$

In those legal systems in which the courts have discretion whether to exercise jurisdiction on the basis of the appropriateness of the forum court, relative to the appropriateness of foreign countries

\footnotetext{
122 Tu and Huang (2020), Section 3, text to note 60.

123 Takahashi (2020), Section 2.1, text to note 11, citing the Kyoto District Court, judgment on 29 January 2015 (2015WLJPCA01296002).

$124 \quad$ Chen (2020), Section 2.8.1, citing the Taiwanese Code of Civil Procedure, Article 182-2 Section 1.

$125 \quad$ Hartley and Dogauchi (2005) p 801, para 48.

126 E.g. Greece (Panopoulos, (2020), Sections 2.4.1 and 2.4.2).

127 E.g. Germany (Weller (2020), Section 3.5).
} 
under the doctrine of forum non conveniens, the parties may be precluded from asserting that a forum nominated as having non-exclusive jurisdiction is inappropriate. In a number of countries, including China, England and the United States, the effect of an optional choice of court agreement is that the defendant is taken to have waived their right to contest the court's jurisdiction. ${ }^{128}$ In England, the parties may not challenge the appropriateness of the nominated court in an optional choice of court agreement - whether the forum or a foreign court - "on grounds foreseeable at the time of the agreement". ${ }^{29}$ In $S \& W$ Berisford plc v New Hampshire Insurance Co Ltd, an influential decision in England and other common law jurisdictions, Justice Hobhouse stated that

"the fact that the parties have agreed in their contract that the English courts shall have jurisdiction (albeit a non-exclusive jurisdiction) creates a strong prima facie case that that jurisdiction is an appropriate one; it should in principle be a jurisdiction to which neither party to the contract can object as inappropriate; they have both implicitly agreed that it is appropriate." 130

Similarly, in Highland Crusader Offshore Partners v Deutsche Bank, a decision of the English Court of Appeal, Lord Justice Toulson stated that

"A non-exclusive jurisdiction agreement precludes either party from later arguing that the forum identified is not an appropriate forum on grounds foreseeable at the time of the agreement, for the parties must be taken to have been aware of such matters at the time of the agreement. For that reason an application to stay on forum non conveniens grounds an action brought in England pursuant to an English nonexclusive jurisdiction clause will ordinarily fail unless the factors relied upon were unforeseeable at the time of the agreement." ${ }^{131}$

Two distinct and inconsistent lines of reasoning as to the effect of optional choice of court agreements have emerged in common law jurisdictions. ${ }^{132}$ The first is that the existence of an optional choice of court agreement, whether in favour of the forum or of a foreign court, is relevant to the normal forum non conveniens enquiry. This is how most optional choice of court agreements are treated in Australia, ${ }^{133}$ and how optional choice of courts in favour of foreign courts are treated in Singapore. ${ }^{134}$ Most state courts in the US "apply the traditional forum non conveniens

\footnotetext{
128 China (Tu and Huang (2020), Section 3, text to note 61); UK (Merrett and Carruthers (2020), Section 2.3.3); US (Buxbaum (2020), Section 5.2.1.2.1). 
analysis, but place a significant burden on the defendant who seeks to dismiss from a forum to which it previously agreed." ${ }^{135}$

If proceedings have been commenced in the courts of two countries, then the existence of parallel proceedings will also be relevant to the forum non conveniens analysis. If one set of proceedings were commenced pursuant to an optional choice of court agreement, this is likely to be given significant weight. In one Canadian case, the fact that the foreign court was nominated in an optional choice of court agreement was a weighty consideration in the Canadian court's decision to stay its proceedings, even though the Canadian court was the court first seised. ${ }^{136}$

The second line of reasoning, which is especially evident in the English cases and has recently been adopted in Singapore, is that the party challenging the jurisdiction of the court nominated in the optional choice of court agreement is bound by their implied promise to submit to the jurisdiction of that court, unless they can show strong cause or reasons as to why they should be allowed to litigate in a non-chosen court. ${ }^{137}$ This is the same test that is applied to exclusive choice of court agreements. Some English cases have used even stronger language. For example, in Mercury Communications v Communications Telesystems International, Justice Moore-Bick stated that

"particular weight should attach to the fact that the defendant has freely agreed as part of his bargain to submit to the jurisdiction. In principle he should be held to that bargain unless there are overwhelming reasons to the contrary." 138

This line of reasoning has been criticised for blurring the distinction between exclusive and optional choice of court agreements. ${ }^{139}$

In some jurisdictions, there are conflicting authorities as to which of these principles should be applied to determine the effect of an optional choice of court agreement. ${ }^{140}$ In common law Canada, the effect of an optional choice of court agreement is normally determined according to the forum non conveniens principle, although Canadian courts sometimes apply the test used for

\footnotetext{
135 Buxbaum (2020), Section 5.2.1.2.1.

136 Silveira v FY International Auditing \& Consulting Corp 2015 ONSC 388, cited by Saumier (2020), Section 3.4.

$137 \quad$ Merrett and Carruthers (2020), Section 2.3.3, text to notes 72-74; Chong (2020), Section 2.3.1. The same approach is taken in Hong Kong (Noble Power Investments Ltd v Nissei Stomach Tokyo Co Ltd [2008] 5 Hong Kong LRD 631).

138 [1999] 2 All England Reports (Comm) 33 (emphasis added). In another case, Justice Gloster stated that "the general rule is that the parties will be held to their contractual choice of English jurisdiction unless there are overwhelming, or at least very strong, reasons for departing from this rule": Antec International Ltd v Biosafety USA Inc [2006] EWHC 47 (Comm), para 7.

139 Chong (2020), Section 2.3.1, text to note 36, citing UBS AG v Telesto Investments Ltd [2011] 4 SLR 503, para 120; Merrett and Carruthers (2020), Section 2.3.3, text to notes 75 and 76, citing BP Plc v AON [2005] EWHC 2554 (Comm), para 23; Highland Crusaders Offshore Partners LP v Deutsche Bank AG [2009] EWCA 725.

$140 \quad$ Common law Canada (Saumier, (2020), Section 3.3).
} 
exclusive choice of court agreements where the choice of court agreement is apparently optional, ${ }^{141}$ and Saumier notes that

"the weight of precedent [may have been] shifting to apply only the strong cause [test] whenever a party is seeking to avoid a choice of court agreement, whether it is the plaintiff or the defendant, whether it is exclusive or optional and whether the agreement designates the forum or a foreign court." 142

In South Africa, while a stay could be granted in a case involving an optional choice of court agreement, it is uncertain whether this would be done by reference to forum non conveniens, or by reference to the principle relevant to exclusive choice of court agreements. ${ }^{143}$

In Abdul Rashid bin Abdul Manaf v Hii Yii Ann, Justice Woo of the Singapore High Court drew a distinction between an optional choice of court agreement which denoted "an" appropriate forum, and a "most appropriate jurisdiction" agreement which denoted "the" appropriate forum. ${ }^{144}$ In the case of a "most appropriate jurisdiction" agreement, "the evidential burden shifts to a plaintiff suing in the non-contractual jurisdiction to show strong cause as to why he should be permitted to do so", in which case "this will bring the negotiated [optional choice of court agreement] very close to an [exclusive choice of court agreement]". ${ }^{45}$ While the Singaporean courts until recently treated any optional choice of court agreement as one factor relevant to the formm non conveniens analysis, the Singaporean Court of Appeal recently held that "where the proper law of the contract is Singapore law and Singapore is a named forum in the optional choice of court agreement, the defendant must show 'strong cause' why he should not be bound to his contractual agreement to submit to the Singapore court's jurisdiction." 146 On the other hand, the effect of an optional choice of court in favour of a foreign court continues to be determined according to the forum non conveniens analysis. ${ }^{147}$

\subsubsection{An agreement that changes character when the option is exercised}

In some countries, optional choice of court agreements are regarded as changing their character when the option is exercised, at which point they become exclusive. This is so in Chinese law, but only in relation to options in favour of Chinese courts. ${ }^{148}$ In English law, it is possible that "a nonexclusive jurisdiction clause may be one which means that a contracting party is entitled to decide

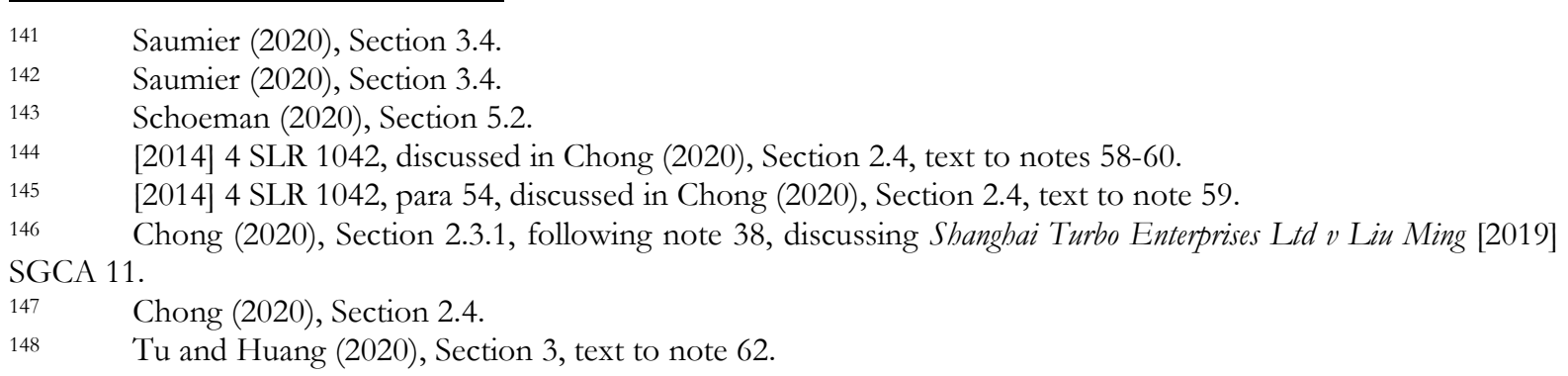


later that the court chosen is to have exclusive jurisdiction, but is under no compulsion to do so." "149 Some US state courts have taken the view that "an optional choice of court agreement "becomes mandatory" once suit is filed in the designated forum"; ${ }^{150}$ and some Belgian scholars take a similar view. ${ }^{151}$ In Singapore, although it is not clear whether the agreement changes character when the option is exercised, the courts will be reluctant to grant an anti-suit injunction if proceedings have not been commenced in Singapore pursuant to the optional choice of court agreement. ${ }^{152}$

\subsubsection{Additional provisions}

Choice of court agreements sometimes include further provisions, in addition to the nomination of a particular court or courts. These additional provisions have been important in the decisions of English courts in cases involving optional choice of court agreements. They might include the nomination of an agent who is authorised to accept service of process within the nominated forum. Some choice of court agreements also include express waivers of the right to object to the jurisdiction of the nominated court. For example, part of the jurisdiction clause in Sabah Shipyard (Pakistan) v Pakistan stated that

"Each Party waives any objection that it may now or hereafter have to the venue of any action or proceeding brought as consented to in this Section 1.9 [the jurisdiction clause], and specifically waives any objection that any such action or proceedings was brought in any inconvenient forum and agrees not to plead or claim the same..."153

Express waivers of the right to challenge jurisdiction might be unilateral. ${ }^{154}$ For example, part of the Law and Jurisdiction clause in Commerzbank, AGv Liquimar Tankers Management Inc provided that

"The guarantor irrevocably waives any objection which it may now or in the future have to the laying of the venue of any proceedings in any court referred to in this clause and any claim that those proceedings have been brought in an inconvenient or inappropriate court." 155

\footnotetext{
$149 \quad$ Briggs (2008), p 115, para 4.16.

$150 \quad$ Buxbaum (2020), Section 5.2.1.2.1.

$151 \quad$ Van Calster and Poesen (2020), Section 3.3.3 (although they disagree with this view).

152 Chong (2020), Section 2.3.3, text to note 103, citing Morgan Stanley Asia (Singapore) Pte v Hong Leong Finance Ltd [2013] 3 SLR 409, para 71.

153 [2003] 2 Lloyd's Rep 571, para 28.

154 E.g. Bambang Sutrisno v Bali International Finance Ltd [1999] 2 SLR(R) 632

155 [2017] 1 WLR 3497, para 9.
} 
In some cases decided by the courts in common law countries, the existence of an express waiver of the right to object to the nominated court seems to have led to the court imposing a higher standard on the party challenging the jurisdiction than is applied in other cases. ${ }^{156}$

Some optional choice of court agreements also include "express other jurisdiction" clauses, which "expressly contemplate the possibility of parallel proceedings". ${ }^{157}$ For example, the clause in Highland Crusaders Offshore Partners v Deutsche Bank stated that "Nothing in this paragraph [containing the choice of court agreement] shall limit the right of any party to take proceedings in the courts of any other country of competent jurisdiction." ${ }^{158}$ In cases in which there are express other jurisdiction provisions, it seems that the courts are likely to take a strict approach, although it has been suggested that the reasoning in these cases should not depend on such a provision because "in any optional jurisdiction agreement there is no promise not to sue in another jurisdiction, thus no agreement that [the nominated forum] is the sole forum, and accordingly there is an inherent risk of parallel proceedings." 159

\subsubsection{Implied promises}

In a number of English cases, the courts have held that an optional choice of court agreement might, depending on the wording of the agreement, entail implied promises that might be enforced in various ways (principally, by the grant of an anti-suit injunction). ${ }^{160}$ These include implied obligations

- not to commence or continue parallel proceedings in a non-nominated forum;

- not to apply for a stay of proceedings in the nominated forum; or

- not to apply for an anti-suit injunction in a non-nominated forum, to prevent commencement or continuation of proceedings in a court nominated in an optional choice of court agreement.

\subsubsection{Discrimination between Options in Favour of Forum and Foreign Courts}

Most legal systems do not openly discriminate in favour of choice of court agreements that nominate forum courts, as opposed to those that nominate foreign courts. For example, in

\footnotetext{
156 Chong (2020), Section 2.3, text to note 32 (citing Transocean Offshore International Ventures Ltd v Burgundy Global Exploration Corp [2010] 2 SLR 821) and Section 2.4, text to note 51 (citing Bambang Sutrisno v Bali International Finance Ltd [1999] 2 SLR(R) 632).

157 Merrett and Carruthers (2020), Section 2.5.3, citing Royal Bank of Canada v Cooperative Centrale [2004] EWCA Civ 7.

158 [2009] EWCA Civ 725.

$159 \quad$ Merrett and Carruthers (2020), Section 2.5.3.

160 Merrett and Carruthers (2020), Section 2.5.3, citing in particular Sabah Shipyard (Pakistan) v Pakistan [2003] 2 Lloyd's Rep 571.
} 
common law systems, optional choice of court agreements whether in favour of the forum or of a foreign court are generally regarded as being relevant to the general forum non conveniens analysis. However, in some countries, optional choice of court agreements in favour of foreign courts are treated differently to those that nominate courts of the forum. ${ }^{161}$ Tu and Huang note that "optional choice of court agreements in favour of Chinese courts on the one hand and those in favour of foreign courts on the other are not treated consistently." ${ }^{162}$ Article 12 of the 2005 Supreme People's Court of China Summary states that an optional choice of court agreement nominating a foreign court does not exclude the jurisdiction of the competent courts of other countries, including China, ${ }^{163}$ even if one party has exercised the option by commencing proceedings in the foreign court nominated in the optional choice of court agreement. ${ }^{164}$ This contrasts with the effect of an optional choice of court agreement in favour of the Chinese courts, which is regarded as becoming exclusive when the option is exercised. ${ }^{165}$

In Australia, an optional choice of court agreement in favour of a foreign court will have little effect. ${ }^{166}$ This is because of the idiosyncratic Australian version of forum non conveniens which requires the defendant to establish that the Australian court is clearly inappropriate, which is far more onerous on the defendant than the version of forum non conveniens developed in England and used in other common law jurisdictions which requires the defendant to show only that a foreign court is clearly more appropriate than the forum. In Australia, the fact that the parties have agreed to submit to the jurisdiction of a foreign court is regarded as merely one factor to take into account in deciding whether the Australian court is clearly inappropriate; Marshall notes that Australian courts have never stayed proceedings in a case in which the parties had nominated foreign courts in an optional choice of court agreement. ${ }^{167}$

\section{Limitations on the Parties' Choice of Court}

Most jurisdictions impose few limitations on the parties' choices of court. One of the main exceptions to this proposition relates to subject matter jurisdiction. This is not contractible, and therefore the forum's rules of exclusive subject matter jurisdiction take priority over the parties' agreements. Most legal systems explicitly nominate particular grounds of exclusive subject matter

\footnotetext{
161 Including Australia (Marshall, (2020), Section 2.3.1.3) and Singapore (Chong (2020), Section 2.5).

162 Tu and Huang (2020), Section 3 (text in the sentence before note 68).

163 Tu and Huang (2020), Section 3 (text to note 64).

164 Tu and Huang (2020), Section 3 (text to note 67).

165 Tu and Huang (2020), Section 3 (text to note 62).

166 Marshall (2020), Section 2.3.1.2.

167 Marshall (2020), Section 2.3.3.1.
} 
jurisdiction, which tend to be fairly similar, including disputes concerning immovable property, ${ }^{168}$ some intellectual property rights, ${ }^{169}$ and some matters involving companies. ${ }^{170}$ In Chinese law, a wide range of subject matters belongs to the exclusive jurisdiction of Chinese courts. These include disputes concerning harbour operations, succession, ${ }^{171}$ performance of contracts within Chinese territory of Chinese-foreign equity joint ventures, Chinese-foreign contractual joint ventures, and Chinese-foreign cooperative exploration and exploitation of natural resources. ${ }^{172}$ In some legal systems, the law identifies the place of exclusive subject matter jurisdiction generally that is, it does not only reserve the exclusive subject matter jurisdiction of the courts of the forum. It is common to find limits on the types of relationships in which a choice of court agreement may be used; for example, many reporters state that choice of court agreements only apply to particular legal relationships, ${ }^{173}$ and some note that the parties cannot use such agreements in family matters. ${ }^{174}$ In Chinese law, the parties are only able to choose courts to deal with contractual disputes and disputes related to property interests. ${ }^{175}$

In most of the countries represented in the national reports, there is no requirement of factual connection to the foreign country the courts of which are nominated in a choice of court agreement. ${ }^{176}$ On the other hand, there is a requirement of factual connection in Chinese law. According to Article 34 of the Chinese Civil Procedure Law,

"Parties to a dispute over a contract or any other right or interest in a property may, without violating rules concerning jurisdiction by forum level and exclusive jurisdiction, choose the court for the place where the defendant is domiciled, or where the contract is performed or signed, or where the plaintiff is domiciled, or where the subject matter is located or any other place that has actual connection with the dispute as the court having jurisdiction over their dispute by a written agreement." ${ }^{\text {177 }}$

The requirement of factual connection has been heavily criticised by Chinese scholars. ${ }^{178}$

\footnotetext{
168 In South African law, the place where land is situated is regarded as having exclusive jurisdiction to deal with questions of title to that land: Schoeman (2020), Section 3.5, text to note 53.

169 E.g. Belgium Van Calster and Poesen (2020), Section 2.2.

$170 \quad$ E.g. Germany (Weller (2020), Section 2.1.1); Japan (Takahashi (2020), Section 1.2, citing the Japanese Code of Civil Procedure, Article 3-10 and 3-5); Turkey (Tarman and Oba (2020), Section 3.1.2).

$171 \quad$ Chinese Civil Procedure Law, Article 33.

172 Chinese Civil Procedure Law, Article 266.

173 In Turkey, the dispute must arise from an "obligatory relationship": Tarman and Oba (2020), Section 3.1.3.

174 Eg Greece (Panopoulos (2020), text to note 2); Netherlands (Rammeloo (2020), Section 1.1); Turkey (Tarman and Oba (2020), Section 3.1.3).

175 Tang, Xiao and Huo (2016), p 69.

176 For example, Japan (Takahashi (2020), Section 1.1).

177 Civil Procedure Law of the PRC (as amended in June 2017), Article 34, cited by Tu and Huang (2020), Section 2 , text to note 6 .

178 Tu and Huang (2020), Section 2 (note 11), citing Tang, Xiao and Huo (2016), p 70; Tang (2012), p 466; Liu and Qi (2014), p 50.
} 
Whereas factual connection may not be a requirement for the validity of a choice of court agreement in most legal systems, the connections to the nominated court might be taken into account when a defendant challenges the choice of court agreement. For example, the Swiss Private International Law Act gives the Swiss court the discretion to decline the submission to its jurisdiction if there is no "local or factual proximity of the court designated by agreement." relevant connections are that either at least one party is domiciled, has its "main whereabouts", or its place of business in the forum; or Swiss law is the governing law. ${ }^{180}$ Similarly, in countries which have a principle of forum non conveniens, factual connections may be relevant in considering whether the proceedings should be stayed or dismissed.

In the Czech Republic, prorogation of a foreign court will only be recognised if there is a "legally significant" international element present. ${ }^{181}$ Under Greek law, a foreign court agreement in a contract that is purely internal to Greece is regarded as invalid on the basis of the theory of fraud a la $10 i{ }^{182}$ In some countries, some reason for the selection of the chosen court is required. ${ }^{183}$ In the 1985 decision of the Dutch Hoge Raad which established that the parties could prorogate the jurisdiction of Dutch courts, the parties' freedom to establish jurisdiction was stated to be subject to their having "a genuine interest". ${ }^{184}$ This does not necessarily require a factual connection; the parties would have a genuine interest if the chosen court was neutral or had relevant expertise. ${ }^{185}$ As noted, the tendency in German law has been the converse of that observed in most other legal systems. The reason for the restrictive approach to the enforcement of choice of court agreements in the 1974 reform to the Code of Civil Procedure was that these agreements were being used in "virtually all standard terms", and their invocation in legal proceedings, particularly involving consumers, was regarded as unfair and abusive. ${ }^{186}$ German law consequently imposes a number of limitations, which are different to those found in most other legal systems. These include that

$179 \quad$ Haas and MacCabe (2020), Section 6.1 (text to note 66), citing the Swiss Private International Law Act, Article 5(3). See likewise Van Calster and Poesen (2020), Section 3.4.2.1, citing the Belgian Private International Law Act, Article 6, paragraph 2.

180 Haas and MacCabe (2020), Section 6.1, text to note 67, citing the Swiss Private International Law Act, Article $5(3)$.

181 Rozehnalová et al (2020), Section 1.1, text to note 10. This requirement is not defined in Czech legislation, and is therefore determined ad hoc in each case. There is similarly a requirement in Turkish law that the dispute must involve a foreign element: Tarman and Oba (2020), Section 3.1.1. As in the case of the Czech Republic, this is not defined, and the courts apply a broad interpretation.

182 Panopoulos (2020), Section 1.1.2.

183 Buxbaum notes that in a few US states, "courts have held that the designated forum 'must bear a reasonable relationship to the transaction"”: (2020), Section 5.1, citing KC Ravens LLC v Nima Scrap, LLC 369 P 3d 341 (Ct App Kansas 2016. She suggests that these decisions are anomalous.

184 Piscator, HR February 1, 1985, NJ 1985, 698, cited by Rammeloo (2020), Section 1.1 (text to note 2).

185 Rammeloo (2020), note 4.

$186 \quad$ Weller (2020), Section 1.4. 
choice of court agreements are only valid if they are concluded between merchants (which generally includes corporations ${ }^{187}$ ), legal persons under public law, ${ }^{188}$ or public trusts. ${ }^{189}$

In some countries, the parties' ability to choose their forum is limited by the application of the forum's internationally mandatory rules. ${ }^{190}$ This is not the case in France, where the Cour de Cassation held in 2008 that the potential application of French lois de police (imperative rules) does not prevent the parties from selecting a foreign court in a choice of court agreement. ${ }^{191}$

Most legal systems will not enforce choice of court agreements in favour of foreign courts when that would be incompatible with fundamental public policy of the forum. ${ }^{192}$ This is likely to affect exclusive rather than optional choice of court agreements. In Japan, the Supreme Court held that effect may be denied to a choice of court agreement if it is "extremely unreasonable and contrary to the law of public policy". ${ }^{193}$ Similarly, a choice of court agreement would not be enforced by Singaporean courts if it was against the fundamental public policy of Singapore. ${ }^{194}$ In Romania, a choice of court agreement will be ineffective "if it abusively deprives one of the parties of the protection ensured by a court designated by Romanian law." 195

\section{Support of Optional Choice of Court Agreements}

In most legal systems, the only protection of optional choice of court agreements is the possibility of proceedings brought in a forum other than that or those nominated in the choice of court agreement being stayed or dismissed, or the court declining jurisdiction. ${ }^{196}$ This might be done on several bases: if the optional choice of court agreement is transformed into an exclusive choice of court agreement once the option is exercised; if the court finds itself to be forum non conveniens, taking into account the existence of the optional choice of court agreement; or if the court stays

\footnotetext{
$187 \quad$ Weller (2020), Section 2.1.7.

188 Similar limitations apply in Turkey, but only in the case of the choice of Turkish courts: Tarman and Oba (2020), Section 4.1.

$189 \quad$ German Code on Civil Procedure, section 38(1).

190 E.g. Australia (Marshall (2020), text to notes 13-14); Belgium (Van Calster and Poesen (2020), Section 2.2).

191 Mailhé (2020), text to note 5, citing Cass civ 1ére 22 October 2008, Monster Cable, no 07-15823, JCP G 2008, 10187, note L d'Avout. The same applies in Greece: Panopoulos (2020), text to note 18)

192 E.g. Czech Republic (Rozehnalová et al (2020), Section 1.3, text to note 36, and Section 2.8, text to note 72); Germany (Weller (2020), Section 3.11).

193 Chisadane, Supreme Court, Judgment, November 28, 1975, 29 Minshu (1) 1554 [1975], cited in Takahashi (2020), Section 1.3. Takahashi notes that although this aspect of the judgment was not explicitly codified in the Code of Civil Procedure, it "arguably has survived the amendment of the [Code of Civil Procedure] since no statutory basis would need to be found to safeguard the fundamental legal value of Japan": (2020), Section 1.3.

$194 \quad$ Chong (2020), Section 1, text to note 3, giving as an example where the parties deliberately chose a foreign court "to evade the operation of the Unfair Contract Terms Act" Cap 396, 1994 Rev Ed.

195 Oprea (2020), Section 4.4, sentence before note 81, citing the Romanian Civil Procedure Code, Article 1068.

196 This is possible in Québec, under the Civil Code, art 3135: see Guillemard and Sabourin (2020), Section 2.2.1, text to note 90 .
} 
or refuses to stay proceedings on the basis of lis pendens, where the relevant court's jurisdiction is derived from the optional choice of court agreement.

Even in common law systems, there are few remedies available to support optional choice of court agreements, in comparison to the range of remedies that support exclusive choice of court agreements. It has been suggested that the "remedies to ensure the optional choice of court agreements' efficacy are not necessarily very efficient." 197

In most countries, damages are definitely not available for breach of an optional choice of court agreement; ${ }^{198}$ it is doubtful whether they are available in Romania. ${ }^{199}$ Van Calster and Poesen suggest that it may be possible that "an abusive exercise of an optional choice of court agreement in favour of the Belgian courts can give rise to an award of damages to the defendant". ${ }^{200}$ Antisuit and anti-enforcement injunctions are not available to support an optional choice of court agreement in most countries. ${ }^{201}$ The courts of EU Member States cannot grant anti-suit injunctions to preclude the commencement or continuation of proceedings in the courts of other Member States. ${ }^{202}$

In common law systems, in addition to staying or dismissing proceedings, and setting aside service of process, the main protection available for choice of court agreements is the anti-suit injunction. ${ }^{203}$ Whereas an anti-suit injunction will readily be issued to prevent the breach of an exclusive choice of court agreement, ${ }^{204}$ that will generally not be the basis on which an anti-suit injunction might be awarded if foreign proceedings have been commenced notwithstanding the parties' optional choice of court agreement in favour of the forum, because this is generally not regarded as a breach of contract. ${ }^{205}$ Instead, the party applying for an anti-suit injunction will need

\footnotetext{
$197 \quad$ Oprea (2020), Section 4.6.

198 Including the Czech Republic (Rozehnalová et al (2020), Section 2.6.2); Greece (Panopoulos (2020), Section

2.6).

199 Oprea (2020), Section 4.6.2.

$200 \quad$ Van Calster and Poesen (2020), Section 3.4.2.2.

$201 \quad$ Including China (Tu and Huang (2020), Section 3 (text following note 81)), Greece (Panopoulos (2020), Section 2.6), Germany (Weller (2020), Section 3.8), , Romania (Oprea (2020), Section 4.6.1), Switzerland (Haas and MacCabe (2020), Section 6.3) and Taiwan (Chen (2020), Section 2.8.3 and 2.8.4).

$202 \quad$ Turner $v$ Grovit [2005] 1 AC 101.

203 This is available, in principle, in Australia (Marshall (2020), Section 2.3.3.3), common law Canada, England and Scotland (Merrett and Carruthers (2020), Section 2.5.3), and Singapore (Chong (2020), Section 2.7, text to notes 95-103). In Scotland, this is referred to as "restraint of foreign proceedings" (Merrett and Carruthers (2020), Section 2.5.3). In common law Canada, there is no case law relating to anti-suit injunctions to protect choice of court agreements in particular: Saumier (2020), Section 4.

204 In England, an anti-suit injunction might be granted to prevent commencement or continuation of proceedings in breach of the exclusive component of an asymmetric choice of court agreement: Merrett and Carruthers (2020), Section 3.5, citing Bank of New York Mellon v GV Films [2009] EWHC 2338 (Comm).

$205 U$ UBS AGv Telesto Investments Ltd [2011] 4 SLR 503, para 75.
} 
to show that the commencement or continuation of the foreign proceedings is unconscionable, vexatious or oppressive. ${ }^{206}$

The English courts alone have in some cases granted anti-suit injunctions to restrain the commencement or continuation of foreign proceedings where the parties had agreed to the nonexclusive jurisdiction of English courts. Unfortunately, "the cases are inconsistent and the principles far from clear." ${ }^{207}$ In Sabah Shipyard (Pakistan) Ltd v Pakistan, ${ }^{208}$ the English Court of Appeal famously upheld the decision of the primary judge to grant an anti-suit injunction to prevent the continuation of foreign proceedings which the court held were brought to frustrate the optional choice of court agreement in favour of the English courts. This was on the basis that the foreign party's conduct was vexatious or oppressive. ${ }^{209}$ On the other hand, the English courts have in some cases refused to grant anti-suit injunctions. ${ }^{210}$ In other common law jurisdictions, an anti-suit injunction might be issued to prevent the commencement or continuation of foreign proceedings, again, if it could be shown that the foreign proceedings were vexatious or oppressive. $^{211}$

In principle, common law courts can grant anti-enforcement injunctions, but there are no cases in which it has been argued or suggested that this remedy might be available to support an optional choice of court agreement. ${ }^{212}$

In principle, in at least some common law countries, damages are available for breach of exclusive choice of court agreements. ${ }^{213}$ It has been suggested that damages should be available for breach of the exclusive component of an asymmetric choice of court agreement. ${ }^{214}$

In comparison, it is generally not regarded as a breach of contract for a party to commence proceedings in a court other than that nominated in an optional choice of court agreement, because such agreements are generally not regarded as imposing an obligation to refrain from litigating in

\footnotetext{
206 Australia (Marshall, (2020), Section 2.3.3.3); UK (Merrett and Carruthers (2020), Section 2.5.3).

$207 \quad$ Merrett and Carruthers (2020), Section 2.5.3.

208 [2003] 2 Lloyd's Rep 571.

209 An injunction was also granted in BNP Paribas SA v Anchorage Capital Europe LLP [2015] EWHC 3077.

$210 \quad$ Merrett and Carruthers (2020), Section 2.5.3, text to notes 109-116, citing Royal Bank of Canada v Cooperative Centrale [2004] EWCA Civ 7; Highland Crusader Offshore Partners v Deutsche Bank AG [2009] EWCA Civ 725; and SwissMarine Corp Ltd v OW Supply \& Trading A/S (in bankruptcy) [2015] EWHC 1571 (Comm).

$211 \quad$ Including Singapore (Chong (2020), Section 2.7).

$212 \quad$ Marshall (2020), Section 2.3.3.4.

213 See Marshall (2020), Section 2.3.3.2 (noting that while there is probably a right to damages for breach of an exclusive choice of court agreement in Australian law, there is no case in which an Australian court has awarded damages); Merrett and Carruthers (2020), Section 2.5.1 (citing Donobue v Armco Inc [2001] UKHL 64; The Alexandros $T$ [2013] UKSC 70). In common law Canada, there is no case law on this issue in particular.

$214 \quad$ Merrett and Carruthers (2020), Sections 2.5.1 and 3.4 (text to notes 98 and 195), citing Barclays Bank plc v Ente Nazionale de Previdenza dei Medici degli Odontoiatra [2015] EWHC 2857 (Comm) paras 127-8. Cf Marshall (2020), Section 2.3.3.2.
} 
courts other than that or those nominated in the optional choice of court agreement. It is highly unlikely that a court would award damages unless the choice of court agreement was more elaborate than simply nominating a court as having optional jurisdiction. In some English cases in which the courts have granted anti-suit injunctions, it has been held that an optional choice of court agreement entails implied promises, including promises not to commence or continue parallel proceedings in a forum other than that nominated; not to apply for a stay of proceedings in the forum; or not to apply for an anti-suit injunction to prevent commencement or continuation of proceedings in a court nominated in an optional choice of court agreement. ${ }^{215}$ Merrett and Carruthers suggest that if "losses have been suffered as a result of a breach of such a promise damages may be recoverable." 216

It is not clear whether damages for breach of a choice of court agreement might be available under the Brussels I Recast Regulation. Several reporters mention that the foreign judgment would give rise to an issue estoppel. ${ }^{217}$ While some regard that as precluding the possibility of damages being awarded, Merrett and Carruthers suggest that

"(a) it could be argued that the procedural consequences of a jurisdiction agreement under the Regulation are different from contractual questions; and (b) furthermore, the effect of Erich Gasser is now reversed by Art 31(2) which does give competence competence to the chosen court." 218

They cite two English cases - The Alexandros $T^{219}$ and Barclays Bank $v$ Ente Nazionale de Presidenza $a^{220}$ - as authority for the proposition that a claim for damages for breach of a choice of court agreement does not infringe the principle of mutual trust and confidence. ${ }^{221}$

\section{Weaker Parties}

In many legal systems, the law reveals serious concerns about the use of choice of court agreements in contracts involving weaker parties, and this is one of the major limitations on the use of choice of court agreements. Some legal systems provide protection to parties who are presumed to be weaker, including consumers and employees, specifically in terms of invalidating, or limiting the effect of, choice of court agreements. This protection may take several forms: it may be implied from the exclusion of such parties from the scope of the instrument, as is done in the Hague

\footnotetext{
215 See above, Section 5.2.3.

$216 \quad$ Merrett and Carruthers (2020), Section 2.5.1.

$217 \quad$ Merrett and Carruthers (2020), Section 2.5.1.

$218 \quad$ Merrett and Carruthers (2020), Section 2.5.1.

219 [2013] UKSC 70, paras 39 and 131-2.

220 [2015] EWHC 2857 (Comm); approved by the Court of Appeal in [2016] EWCA Civ 1261.

221 Compare Rozehnalová et al (2020), Section 2.6.2.
} 
Choice of Court Convention, ${ }^{222}$ or it may be explicit in specific rules that apply only to choice of court agreements involving weaker parties, as in the Brussels I Recast ${ }^{223}$ and in national laws of some countries. Countries including China, ${ }^{224}$ the Czech Republic, ${ }^{225}$ Germany, ${ }^{226}$ Greece, ${ }^{227}$ Japan, ${ }^{228}$ Switzerland, ${ }^{229}$ Turkey, ${ }^{230}$ and the US ${ }^{231}$ provide specific protection for weaker parties. Specific protective rules in favour of weaker parties generally do not distinguish between exclusive and optional choice of court agreements, ${ }^{232}$ although some, such as those invalidating choice of court agreements that exclude a weaker party's right to bring proceedings in the forum, would obviously only apply to an exclusive choice of foreign courts.

In some countries, choice of court agreements involving presumptively weaker parties are completely unenforceable. $^{233}$ For example, under the Civil Code of Québec, a choice of court agreement which nominates a foreign court cannot be enforced against a consumer or employee who is domiciled in Québec. ${ }^{234}$ It is more common that the choice of court agreement is not completely invalid; generally, it can be invoked by the weaker party, and only invoked against the weaker party in limited circumstances. For example, in the Brussels I Recast Regulation, a choice of court agreement involving insureds, consumers, and employees can be enforced if the agreement gives the weaker party a selection of courts other than those that would otherwise be available under the default rules. ${ }^{235}$ In Taiwan, the legal protection of weaker parties only enables proceedings to be transferred from the chosen Taiwanese court to another competent Taiwanese court. $^{236}$

\footnotetext{
$222 \quad$ Article 2(1).

223 Sections 3 (dealing with insurance contracts), 4 (dealing with consumer contracts) and 5 (dealing with employment contracts).

224 Tu and Huang (2020), Section 3 (text to note 75), citing Article 31 of the Supreme People's Court of China Interpretation on Chinese Civil Procedure Law.

225 Rozehnalová et al (2020), Section 2.5, citing the Czech Private International Law Act, sections 86 and 88.

$226 \quad$ Weller (2020), Section 3.7.

227 Panopoulos (2020), Sections 1.1 .2 and 2.5

228 Takahashi (2020), Section 2.2, citing the Japanese Code of Civil Procedure, article 3-7.

229 Haas and MacCabe (2020), Section 10, citing the Swiss Code on Civil Procedure, article 35(1), Lugano Convention, articles 13, 17, 21, and the Swiss Private International Law Act, article 114(2).

$230 \quad$ Tarman and Oba (2020), Section 3.2.

231 Buxbaum (2020), Section 3.2.

232 For example, in Chinese law, a choice of court agreement in a consumer contract is invalid unless the consumer receives "proper notice" of the terms: Tu and Huang (2020), Section 3 (text to note 75).

233 This is so for most choice of court agreements involving weaker parties in German law: Weller (2020), Section 3.7. See also Panopoulos (2020), describing the unenforceability of contracts involving weaker parties under Greek law of national origin: Section 1.1.2 (referring to agreements in some employment matters, in favour of foreign courts), Section 2.5.3 (referring to consumer agreements which are "concluded or to be executed in Greece").

$234 \quad$ Article 3149.

$235 \quad$ Articles 15(2), 19(2), and 23(2).

236 Chen (2020), Section 2.7, citing Taiwanese Code of Civil Procedure, Article 28 section 2.
} 
The inclusion of such protective provisions is for most legal systems a new legal development. ${ }^{237}$ Laws protecting consumers and employees are the most common, but in other legal systems they extend also to insureds. In the Swiss Code on Civil Procedure, tenants are also presumed to be weaker; ${ }^{238}$ laws in US states protect a range of other parties presumed to be in a weaker bargaining position, including franchisees. ${ }^{239}$

In some countries, the primary laws make no particular provision for the protection of weaker contracting parties in the specific context of choice of court agreements. ${ }^{240} \mathrm{It}$ is typical of common law countries that there are no specific protections for weaker parties in the principles of jurisdiction. ${ }^{241}$ Disputes about choice of court agreements involving weaker parties are, in general, resolved using the same principles as those applicable in other cases. ${ }^{242}$ A small number of cases suggest that exclusive choice of court agreements involving consumers require slightly different treatment. ${ }^{243}$ The implications of those cases for optional choice of court agreements involving consumers are not clear, but it stands to reason that in a choice of court agreement involving a consumer, the agreement should be given less weight. ${ }^{244}$

\section{Asymmetric Choice of Court Agreements}

The decision of the French Cour de Cassation in Madame Xv Société Banque Privé Edmond de Rothschild ${ }^{245}$ has attracted a great deal of attention, and stimulated controversy internationally about the effect of asymmetric choice of court agreements, sometimes called unilateral, or one-sided, choice of court agreements. While asymmetric agreements take different forms, the most common contains a combination of an exclusive choice of court agreement, which applies if one party commences proceedings, and an optional choice of court agreement, which applies if the other party commences proceedings.

237 Takahashi notes that prior to the amendment of the Japanese Code of Civil Procedure which came into effect in 2012, "no special treatment was given to individual employment relations" in the context of choice of court agreements: (2020), Section 1.3 .

$238 \quad$ Article 35, cited in Haas and MacCabe (2020), Section 10.

239 Buxbaum (2020), Section 3.2.

240 This is particularly true in common law countries.

241 This is so in Australia (Marshall (2020), Section 2.3.2); Singapore (Chong (2020), Section 2.6), the UK (Merrett and Carruthers (2020), Section 2.4); and in the US (Buxbaum (2020), Section 3.3).

$242 \quad$ For example, in the 2017 decision of the Canadian Supreme Court in Donez v Facebook Inc, involving an exclusive choice of court agreement between Facebook and Canadian users of Facebook services, the court used the same principles as those that are applied in commercial cases: 2017 SCC 33. See Saumier (2020), Section 3.2.

243 Most importantly, in Douez. v Facebook, Inc, 2017 SCC 33 the majority of the Supreme Court of Canada took the view that the consumer context required a "differentiated application of the "strong cause" test for refusing to enforce a choice of court agreement": Saumier (2020), Section 3.2.

$244 \quad$ Marshall (2020), Section 2.3.2.

245 Cass civ, 1ère, 26 September 2012. 
While asymmetric choice of court agreements are not rare, they have not been the subject of much litigation. ${ }^{246}$ Evidently, in most countries there are no specific statutory rules relating to their enforcement, ${ }^{247}$ and so, to the extent that the question of their effectiveness has arisen in practice, the principles are derived from case law.

In France, choice of court agreements "in the sole interest of one party" have long been recognised: "[s]uch optional choices were discovered by interpretation: the agreement was found to allow the party the clause had been written in favour of to renounce his right and to seize an otherwise competent court." ${ }^{248}$ In Greece, choice of court agreements "for the benefit of one of the parties, as envisaged in Art $17 \$ 5$ [of the Brussels Convention], are steadily accepted as valid in the Greek legal order under provisions of national origin". ${ }^{249}$

The effect of asymmetric choice of court agreements under the Brussels I Recast Regulation is particularly unclear. The recent decisions of the French Cour de Cassation have in particular attracted a great deal of attention. The Cour de Cassation has now refused to enforce asymmetric choice of court agreements in four cases, including the Rothschild case. ${ }^{250}$ In another two cases, eBizcuss ${ }^{251}$ and Diemme Enologia vs Etablissements Chambon \& fils ${ }^{252}$ it held an asymmetric choice of court agreement to be enforceable. In England, on the other hand, an asymmetric choice of court agreement has been held valid under the Recast. ${ }^{253}$ In Commerzbank AGv Liquimar Tankers Management Inc, Justice Cranston held that Article 31(2) of the Recast applied to the exclusive component of asymmetric choice of court agreements. ${ }^{254}$ Joseph suggested that a choice of court agreement which benefited only one party "would simply be an example of parties making specific provision other than by way of 'exclusive jurisdiction' binding on both parties." 255 He suggested that this is because of the respect that the Recast requires for party autonomy, and that "there is therefore no reason not to uphold such a bargain." 256

There are conflicting views as to whether asymmetric choice of court agreements come within the scope of the Hague Choice of Court Convention. One view is that the Convention does not apply

\footnotetext{
246 Chong notes that in Singapore " $[\mathrm{t}]$ here appear to be few reported cases dealing expressly with asymmetrical choice of court agreements and of those few, the optional portion of such agreements has not been at issue": (2020), Section 4. See similarly, in relation to Belgium, Van Calster and Poesen (2020), Section 4.2.

247 This is so, for example, in Switzerland (Haas and MacCabe (2020), Section 11).

$248 \quad$ Mailhé (2020), text to note 13.

$249 \quad$ Panopoulos (2020), Section 1.3.1.3, citing the Greek Code of Civil Procedure, Art 44.

$250 \quad$ The other cases are Danne Holdings v Crédit Suisse Cass civ 1ère, 25 March 2015, Crédit Suisse II Cass. civ. 1e., 7 February 2018and Saint-Joseph Cass. civ. 1e., 3 October 2018, discussed by Mailhé (2020), Section 3.

251 Société eBizcuss.com v Apple Cass. civ. 1ère, 7 October 2015, discussed by Mailhé (2020), at text to note 41.

252 Cass. civ. 1ère, 11 May 2017, discussed by Mailhé (2020), at text to notes 42-44.

253 Commerzbank AGv Liquimar Tankers Management Inc [2017] 1 WLR 3497.

$254 \quad$ [2017] 1 WLR 3497, para 64.

$255 \quad$ Joseph (2015), p 98, para 3.79

$256 \quad$ Joseph (2015), p 73, para 3.18.
} 
to them at all. This view derives from the Explanatory Report on the Convention, which states that asymmetric agreements are "non-exclusive for the purpose of the Convention because they exclude the possibility of initiating proceedings in other courts for only one of the parties." ${ }^{257}$ Some commentators base their view, that the Convention does not apply to asymmetric choice of court agreements, on this statement from the Explanatory Report. ${ }^{258}$ The contrary view is proposed by Justice Cranston in dicta in Commerzbank, AGv Liquimar Tankers Management Inc, where he said that "there are good arguments in my view that the words of the definition in article 3(a) of the Hague Convention cover asymmetric jurisdiction clauses." 259 Merrett and Carruthers agree, suggesting that if the exclusive component is in issue, it should come within the scope of the Hague Convention. ${ }^{260}$

In some countries the legal effects of asymmetric choice of court agreements are unknown under national laws because their effects are not explicitly provided for in legislation and have not been tested in case law. ${ }^{261}$ Most national reporters in the remaining countries state that asymmetric agreements are regarded as valid. ${ }^{262}$ However, in the Czech Republic, scholars continue to criticise them for "lack of clarity", ${ }^{263}$ whereas they are enforced in some cases, at least between commercial parties; and in Turkey, there are inconsistent views about the validity of asymmetric choice of court agreements. ${ }^{264}$ In those legal systems that have explicit protections for weaker parties, the effectiveness of an asymmetric agreement involving a weaker party is subject to those controls. ${ }^{265}$ Concerns about asymmetric agreements are almost always due to the fact of their being used in contracts involving weaker parties. ${ }^{266}$ Van Calster and Poesen suggest it is possible that the "Belgian courts might subject asymmetrical choice of court agreements to the requirement of good faith". 267

It is common, in those legal systems in which asymmetric agreements have been litigated, that the different components are treated separately, depending on which aspect of the agreement is in

\footnotetext{
257 Hartley and Dogauchi (2005) p 845, para 249. See also p 811, paras 105-106.

$258 \quad J o s e p h$ (2015), p 73, para 3.18; Chong (2020), Section 4, text to note 108-110.

259 [2017] 1 WLR 3497, para 74, cited by Merrett and Carruthers (2020), Section 3.3.

$260 \quad$ Merrett and Carruthers (2020), Section 3.3.

261 E.g. common law Canada (Saumier (2020), Section 5), Romania (Oprea (2020), Section 5.1.3, text to note 125).

262 This is so in Germany (Weller (2020), Section 4); the Netherlands (Rammeloo (2020), Section 3.2); and the US (Buxbaum (2020), Section 3.4).

263 Rozehnalová et al (2020), Section 3.1.

264 Tarman and Oba (2020), Section 5.

265 This is so in Taiwan: Chen (2020), Section 3.1, citing the Taiwanese Code of Civil Procedure, Article 28 Section 2.

$266 \quad$ Mailhé (2020), Section 2.2, text to notes 33-35.

$267 \quad$ Van Calster and Poesen (2020), Section 4.3.3.
} 
issue. ${ }^{268}$ Exclusive components are treated as simple exclusive choice of court agreements, and optional components are treated as simple optional choice of court agreements. ${ }^{269}$ In China, an asymmetric choice of court agreement was held to be valid in one case; its effect was said to depend on whether the investor or the bank commenced proceedings. ${ }^{270}$ The courts held that if the investor commenced proceedings, the nominated courts would have exclusive jurisdiction, whereas if the bank commenced proceedings, the courts would have only non-exclusive jurisdiction.

In some countries, a choice of court agreement which left the choice of court entirely to the option of the plaintiff would not be enforceable. ${ }^{271}$ In Germany, it is impermissible to leave the choice of court entirely to the plaintiff, because this would be insufficiently precise. ${ }^{272}$ In German law, "the asymmetry raises issues of fairness and abuse", ${ }^{273}$ and there are a range of controls to prevent this, including where one party "exploited its economic or social power" in compelling the weaker party to agree to the asymmetric agreement, and where the weaker party's access to justice is impaired, either legally or practically, "to an intolerable extent". ${ }^{274}$ The controls are stronger where the asymmetric agreement is contained in standard terms. ${ }^{275}$

Common law courts, particularly the English courts, and most common law commentators ${ }^{276}$ do not see any problem with asymmetric choice of court agreements. English courts have given effect to them in under national law, the Brussels Convention, the Lugano Convention, and the Recast. ${ }^{277}$ The English judges have stated that the fact that such agreements give an advantage to one party is not unusual in contracts generally and is not a cause for concern. ${ }^{278}$ English commentators insist that there is nothing wrong with the parties reaching an agreement as to jurisdiction that is neither simply exclusive nor simply optional. Briggs asserted that

\footnotetext{
268 Japan (Takahashi (2020), Section 3.1), Singapore (Chong (2020), Section 4), and the UK (Merrett and Carruthers (2020), Section 3).

269 Australia (Marshall (2020), Section 4); Japan (Takahashi, (2020), Section 3.2).

270 Laiv ABN AMRO Bank NV, the Shanghai High People's Court (2010) Hu Gao Min Wu (Shang) Zhong Zi No 49, cited by Tu and Huang (2020), Section 4, text to notes 102-3.

$271 \quad$ Germany (Weller (2020), Section 2.1.1, text to note 55).

$272 \quad$ Weller (2020), Section 4, text to note 163.

273 Weller (2020), Section 4, text to note 162.

$274 \quad$ Weller (2020), Section 4, text to notes 167-8.

275 Weller (2020), Section 4, text to note 171

$276 \quad$ E.g. Briggs (2008), pp 120-1, para 4.24.

277 These include Commerzbank AG v Liquimar Tankers Management Inc [2017] 1 WLR 3497; Barclays Bank plc v Ente Nazionale di Previdenza ed Assistenza dei Medici e Degli Odontoiatri [2015] 2 Lloyd's Rep 527; Mauritius Commercial Bank Ltd v Hestia Holdings Ltd [2013] 2 All ER (Comm) 899; Lornamead Acquisitions Ltd v Kaupthing Bank HF [2013] 1 BCLC 73; and Continental Bank NAv Aeakos Cia Naviera SA [1994] 1 WLR 588.

$278 \quad$ Merrett and Carruthers (2020), Section 3.1.1, text to notes 144-145 (citing NB Three Shipping Ltd v Harebell Shipping Ltd [2014] EWHC 2001 and Law Debenture Trust Corporation plc v Elektrim Finance BV [2005] EWHC 1412 (Ch), para 46.
} 
"there is no apparent reason why parties may not, if so advised, make an agreement for the resolution of disputes which is more complex, and better suited to their needs, than would be provided by a plain and simple "exclusive or non-exclusive" template." 279

In those legal systems which impose general restrictions on the use of choice of court agreements involving weaker parties, those restrictions would be applied to asymmetric agreements. ${ }^{280}$ There are other substantive provisions under the national laws of some countries which might have the effect of limiting the effect of an asymmetric choice of court agreement. For example, Takahashi suggests that a new provision of the Japanese Civil Code, due to come into force on 1 April 2020, which states that any contractual clause in a standard transaction "which purports to restrict the rights or add to the obligations of the other party [ie the offeree] shall be deemed not to have been consented to if it is considered to harm the interests of that other party unilaterally" will apply to an asymmetric choice of court agreement contained in a commercial contract. ${ }^{281}$

One particularly tricky problem associated with asymmetric choice of court agreements is determining the governing law. Referring to the law of the chosen court is unhelpful because there are multiple courts chosen, which might be problematic, given that different legal systems take different views as to the validity of such agreements. Referring to the law of the forum might encourage forum shopping, given the diversity in regulation of asymmetric choice of court agreements. A possible solution would be to refer to the law governing the contract in which the choice of court agreement is contained.

\section{Optional Choice of Court Agreements in Intra-national Cases}

In some countries, including Canada, China and Greece, optional choice of court agreements in intra-national cases are not treated any differently to those in international cases. ${ }^{282}$ In Germany, the same principles are applied to intra-national cases and those international cases which are subject to German national law. ${ }^{283}$

In other legal systems, choice of court agreements in intra-national cases are treated somewhat differently to those in international cases. In Japan, "the tendency of the courts in intra-national cases is to deem a choice of court agreement to be optional unless the contrary intent is clear". ${ }^{284}$ This is the converse to international cases, in which the Japanese courts tend to treat choice of

\footnotetext{
$279 \quad$ Briggs (2012), p 376.

280 This includes Japan: Takahashi (2020), Section 3.2, text to notes 20-21.

281 Takahashi (2020), Section 3.2, citing the Japanese Civil Code, new Article 548-2.

$282 \quad$ Guillemard and Sabourin (2020), Section 2.3; Tu and Huang (2020), Section 3 (text to notes 89 and 90); Panopoulos (2020), Section 2.4.3.

$283 \quad$ Weller (2020), Section 3.10.

284 Takahashi (2020), Section 2.4, text to note 18.
} 
court agreements as exclusive. There are no special jurisdictional rules for protecting consumers and employees in the intra-national context, unlike the international context. After the amendment to the Japanese Code of Civil Procedure which inserted special provisions for protecting such weaker parties in the international context, Takahashi suggests that "if the different treatment of intra-national and international cases persists, the presence and absence of special rules for protecting weaker parties may furnish an explanation". ${ }^{285}$

In Australia, there is a significant difference between the effect of optional choice of court agreements in intranational, compared to international, cases. ${ }^{286}$ While in both cases optional choice of court agreements in favour of the forum were likely to be given significant weight, optional choice of court agreements in favour of other courts were much more likely to be regarded as a "strong indication" of the parties' intentions as to venue in intranational cases, ${ }^{287}$ whereas in international cases, Australian courts have never stayed proceedings in cases involving optional choice of court agreements in favour of foreign courts. ${ }^{288}$

\section{The Recognition of Foreign Judgments}

In most countries, a judgment rendered by a foreign court nominated by the parties in an optional choice of court agreement would be recognised, assuming that other requirements of recognition are satisfied. ${ }^{289}$ Whereas judgments rendered by foreign courts other than that which the parties nominated as having exclusive jurisdiction would not be recognised in some countries, ${ }^{290}$ there is no such limitation on the recognition of foreign judgments rendered by courts other than those nominated in an optional choice of court agreement. ${ }^{291}$

As noted, the main practical difficulty with optional choice of court agreements is that they do very little to limit the prospect of parallel proceedings. Although this may be controlled in many cases by the principles of lis pendens, or forum non conveniens, there remains the prospect that, in a case involving an optional choice of court agreement, judgment is rendered by more than one court in the same matter, where one court's jurisdiction was founded on the parties' agreement. This possibility is addressed in the Hague Choice of Court Convention, which (as noted above),

\footnotetext{
285 Takahashi (2020), Section 2.4, final para.

286 Marshall (2020), Section 2.4.

$287 \quad$ Marshall (2020), Section 2.4.

$288 \quad$ Marshall (2020), Section 2.3.3.1.

289 Japan (Takahashi (2020), Section 1.1); Taiwan (Chen (2020), Section 2.8.4).

290 Although there is no such indirect protection of exclusive choice of court agreements in the Brussels I Recast. See Panopoulos (2020), Section 1.3.3.3, citing Greek Code of Civil Procedure, Article 323(2).

$291 \quad$ Including Australia (Marshall (2020), Section 2.3.3.5); the Czech Republic (Rozehnalová et al (2020), Section 2.6.3); Germany (Weller (2020), Section 3.9); Romania (Oprea (2020), Section 4.6.3); Singapore (Chong (2020), Section 2.7, text following note 88); Taiwan (Chen (2020), Section 2.8.5).
} 
enables contracting states to make a declaration that they will recognise judgments of the courts of other contracting states, which were nominated by the parties as having non-exclusive jurisdiction, and which have also made a declaration under Article 22. ${ }^{292}$ Article 22(2) anticipates the possibility of multiple proceedings, and addresses this by stipulating that the judgment will only be recognised if

“b) there exists neither a judgment given by any other court before which proceedings could be brought in accordance with the non-exclusive choice of court agreement, nor a proceeding pending between the same parties in any other such court on the same cause of action; and

c) the court of origin was the court first seised."

\section{Justifications for Enforcing Choice of Court Agreements}

While there has been a rapid increase in the volume of laws and commentary on choice of court agreements, there has been relatively limited discussion of the justifications for the enforcement of agreements on choice of court. It is generally assumed that the benefits of agreements speak for themselves, and that as much as party autonomy might be beneficial in other contexts, it can be assumed to be beneficial in the context of choices of court.

A number of arguments are made in favour of the enforcement of agreements about dispute resolution. Most of these arguments are not specific either to the context of international dispute resolution, or to the issue of jurisdiction, and therefore many of these justifications are also found in the context of the use of agreements in domestic private law and domestic civil procedure: indeed, one argument in favour of the use of agreements in the context of international litigation is that this is consistent with the domestic law of obligations. Many of these arguments are proposed at a level of generality and abstraction, and almost all assume that the choice of court agreement is exclusive. There has been very limited discussion of the justification for the enforcement of optional choice of court agreements, in particular.

The justifications include that enforcing agreements creates or enhances legal certainty and predictability. ${ }^{293}$ This has two applications. The first relates to enabling the parties to predict how any jurisdictional dispute between them would be resolved, and the second, to establishing the legal framework for the main contract. The first aspect of certainty - enabling the parties to anticipate the resolution of a jurisdictional dispute - is particularly important in relation to the

\footnotetext{
292 To date, none of the contracting states has entered this reservation.

293 This is referred to by the European Court of Justice in cases such as Benincasa v Dentalkit Srl [1997] ECJ Case C-269/95, para 29; and Trasporti Castelletti [1999] ECJ Case C-159/97, para 48. See also Van Calster and Poesen (2020), Section 2.1.
} 
selection of forum because, so the argument goes, without a choice of court agreement, it is very likely that any dispute could be heard in the courts of a number of different countries because of the expansive circumstances in which the courts of most legal systems assert jurisdictional competence. Further exacerbating this problem, disputes about the allocation of jurisdiction in the absence of any agreement are resolved according to default principles that are regarded as being problematic. The default principle of lis pendens is regarded as too blunt, if not liable to incentivise the hasty commencement of proceedings, and therefore disincentivise and frustrate amicable settlement of disputes. The default principle of forum non conveniens on the other hand is regarded as too unpredictable, if not unfair to foreign defendants. Both types of default principle, in conjunction with broad rules of jurisdictional competence, are also criticised for their propensity to foster forum shopping. The use of choice of court agreements therefore is promoted on the basis that it minimises the scope for opportunistic, unilateral forum shopping.

It will be obvious that the foregoing argument applies best to, and indeed is usually made in the context of, exclusive choice of court agreements. In some cases, courts have commented on the value of exclusive choice of court agreements in creating certainty. For example, in Armacelv Smurfit Stone Container Corp, Justice Jacobson of the Federal Court of Australia said that the choice of court agreement had to be interpreted

"against the background that this was a contract made between business people negotiating at arms' length who must be presumed to have intended some certainty as to where their disputes would be litigated....It is therefore difficult to see why they would not have intended that all their disputes be resolved in New South Wales." 294

The assumption that reasonable business people would not intend a multiplicity of proceedings is also relevant in the broad interpretation applied in some countries to the material scope of choice of court agreements. ${ }^{295}$

The application of arguments about certainty to optional choice of court agreements is very complicated. Optional choice of court agreements merely create an option for one party, or both, to commence proceedings in a nominated court, or several nominated courts. Because they do not necessarily affect the parties' ability to commence proceedings in courts other than that or those nominated, they do not reduce the number of potential forums, and clearly, they do not do so to the same degree that exclusive choice of court agreements do. It is therefore questionable whether they can be defended on the basis that they create legal certainty.

\footnotetext{
$294 \quad$ [2008] FCA 592, para 88.

295 Germany (Weller (2020), Section 2.1.5, text to note 77, referring to the assumption that "reasonable business parties typically ... want to avoid several proceedings about the same facts in different courts").
} 
The second aspect of the argument that choice of court agreements create certainty is that the parties need to know the legal framework for their contract (particularly, the forum in which any disputes will be resolved) in order appropriately to draft the contract, ${ }^{296}$ and to perform their obligations under it. This argument has a much weaker application in the context of optional choice of court agreements than in the context of exclusive choice of court agreements, unless the parties nominate only one court.

According to an economic analysis of law, the use of agreements is desirable because of consumer sovereignty: that is, the parties are better judges of what is in their interests than any third party, including a court. Economic analysts also argue that if agreements are strictly enforced, the private and public costs of dispute resolution will be reduced. Optional choice of court agreements do not lend themselves to strict enforcement in the way that exclusive choice of court agreements do. The principle of lis pendens is usually applied in a strict way; but it is not possible to predict which court will be first seised. The principle of forum non conveniens has also been criticised as making it difficult to predict whether a court will decline jurisdiction. Under either principle, there is not a strong argument that the use of optional choice of court agreements will be efficient.

Enforcing agreements is also justified on the basis that the agreement generates reasonable or legitimate expectations by the parties that should be protected. This argument is circular because the expectation can only be legitimate or reasonable if it reflects the legal status of agreements.

The enforcement of agreements is usually justified primarily on the basis that it promotes respect for party autonomy. ${ }^{297}$ For example, recital 19 of the Preamble to the Brussels I Recast Regulation states that

"The autonomy of the parties to a contract, other than an insurance, consumer or employment contract, where only limited autonomy to determine the courts having jurisdiction is allowed, should be respected subject to the exclusive grounds of jurisdiction laid down in this Regulation."

Almost all of the above referenced discussion about the justifications for enforcing choice of court agreements assumes that the choice of court agreement is exclusive. Whereas exclusive choice of court agreements are generally regarded as being highly rational (because they generate a high degree of certainty about forum), there is a perception that optional choice of court agreements are the opposite. In the influential English case Sohio Supply Cov Gatoil (USA) Inc, Lord Justice Staughton said that he could

\footnotetext{
$296 \quad$ Hartley (2013), p 4, para 1.01.

297 Schoeman (2020), Section 3.3, text to notes 34 and 35, citing MV Spartan-Runner v Jotun-Henry Clark Ltd 1991 (3) SA 803 (N), 806G-H and Blanchard, Krasner \& French v Evans 2002 (4) SA 144 (T), para 11; and Foize Africa (Pty) Ltd $v$ Foize Beheer BV and Others 2013 (3) SA 91 (SCA), para 28(a).
} 
"think of no reason at all why [the parties] should choose to go to the trouble of saying that the English courts should have non-exclusive jurisdiction. I can think of every reason why they should choose that some court, in this case the English court, should have exclusive jurisdiction. Then, both sides would know where all cases were to be tried." 298

Guillemard and Sabourin also question the utility of optional choice of court agreements, given that the legal certainty generated by such agreements tends to be very limited. ${ }^{299}$

Clearly, there are reasons for using optional choice of court agreements that might be quite rational. Briggs points out that

"Agreeing in advance that a particular court or courts would, as far as the parties are concerned, be available, would reduce the risk of jurisdictional challenges if proceedings are brought before them; but for the parties to tie their hands to litigation in a court which may become unattractive in the period between the making of the contract and the dispute arising is not always sensible." 300

That is particularly so if one party is, or its assets are, mobile, in which case, the flexibility which optional choice of court agreements offer may be attractive at least to one party. ${ }^{301}$

One reason that optional choice of court agreements are regarded as irrational is that they do not eliminate or substantially reduce the prospect of parallel proceedings. Not only is this prospect problematic from the perspective of public policy, but it has also been regarded as being, in general, unlikely to reflect the intentions of rational businesspeople. Guillemard and Sabourin suggest that optional choice of court agreements encourage a race to commence proceedings. ${ }^{302}$

\section{Reform}

The national reports demonstrate that there are many unresolved issues associated with the effects of optional choice of court agreements. Even in those countries where the law in relation to optional choice of court agreements is relatively well developed, there remain a number of issues that have not been determined, and incompatible decisions. These issues do not appear to have attracted the attention of lawmakers, in that none of the national reports refers to current reform projects. A few national reporters take the view that there is no obvious need for reform to the law, whereas others suggest reform is required. The latter tends to be the case in those countries in which the recognition of choice of court agreements is relatively recent. But most reporters

\footnotetext{
298 [1989] 1 Lloyd's Rep 588, 591-2.

$299 \quad$ Guillemard and Sabourin (2020), Introduction, text following note 17.

$300 \quad$ Briggs (2008), pp 114-5, para 4.15.

$301 \quad$ Oprea (2020), Section 1.2, text in para above note 16.

302 Guillemard and Sabourin (2020), Introduction.
} 
identify aspects of the law relating to the effect of optional choice of court agreements which would benefit from greater clarity and certainty.

Aspects of the law which have been identified as being problematic and therefore requiring reform include a lack of certainty on the distinction between exclusive and optional choice of court agreements; ${ }^{303}$ a lack of clarity on the governing law to determine whether a choice of court agreement is optional or exclusive; ${ }^{304}$ a lack of consistency in the treatment of optional agreements; ${ }^{305}$ a lack of consistency in the treatment of optional choice of court agreements in favour of the forum and those in favour of foreign courts; ${ }^{306}$ and a lack of consistency in the treatment of optional choice of court agreements in international and intranational cases. ${ }^{307}$ It has been suggested that the general lis pendens rule may not be suitable to resolve parallel proceedings where one of the courts' jurisdiction is derived from an optional choice of court agreement. ${ }^{308}$ The national reports also disclose some quite significant differences in the definition of and treatment of optional choice of court agreements, which means that if there are parallel proceedings, the same choice of court agreement may well be given very different effects in the different legal systems. Several reporters also suggest that greater clarity is required in terms of the effect of asymmetric choice of court agreements.

Some of the national reporters include suggestions for the reform of the law. In particular, it is suggested that it would be desirable to develop statutory solutions to maximise certainty and clarity. There is a fairly high level of support for the Hague Choice of Court Convention, but those reporters who suggested that their country acceding to the convention would be an improvement do not comment on whether they also support their country making a declaration under Article 22 , which indirectly addresses the treatment of optional choice of court agreements.

\section{Conclusion}

The national reports confirm that there have been significant changes in the law relating to the effect of choice of court agreements. They also show convergences in terms of the legal effect of choice of court agreements, particularly in terms of a widespread acknowledgment of the virtues

\footnotetext{
303 Eg Japan (Takahashi (2020), Section 4); South Africa (Schoeman (2020), Section 6). Weller notes this issue but also suggests that "this is a minor problem because it is easy for the parties to express themselves clearly in this respect.”: (2020), Section 5.

$304 \quad V a n$ Calster and Poesen note that the parties "can minimize the risk of litigation on this issue by explicitly subjecting the optional choice of court agreement to one particular law": (2020), Section 3.3.2 (text to note 43).

305 Common law Canada: Saumier (2020).

$306 \quad$ Australia (Marshall (2020), Sections 2.3.1.3 and 5); Singapore (Chong (2020), Section 5, para 3).

$307 \quad$ Marshall (2020), Section 2.4.

$308 \quad$ Oprea (2020), Section 6.
} 
of party autonomy. This convergence is reflected in the Brussels instruments, particularly the Recast, which has had a strong influence within the European Union Member States, ${ }^{309}$ but also influenced the development of the law further afield. ${ }^{310}$ The Brussels I Recast was designed to integrate with the Hague Choice of Court Convention. That Convention creates the possibility of greater international coordination in the treatment of choice of court agreements, but so far has not been widely adopted beyond the European Union. In all events, the Hague Convention only deals directly with exclusive choice of court agreements, and the Brussels I Recast only modified the treatment of exclusive choice of court agreements, leaving other choice of court agreements regulated by the default principle of lis pendens.

The most significant recent development in relation to optional choice of court agreements concerns the now common, although not universal, position that the parties' agreement as to forum is effective in establishing the competence of a court to hear a dispute, notwithstanding a lack of any factual connection to the chosen court.

There remain important differences between the legal treatment of optional choice of court agreements internationally. For example, the conceptualisation and treatment of optional choice of court agreements in common law jurisdictions is fairly similar, but important differences persist between the common law treatment of such agreements, and the treatment in other legal systems. This is clearly evident in the kinds of remedies available to support optional choice of court agreements. There are also significant differences in terms of the legal treatment of asymmetric agreements, and agreements involving weaker parties.

As Briggs observed,

"though the expression 'non-exclusive jurisdiction clause' may suggest it describes a class of terms which is as internally coherent as that of exclusive jurisdiction clauses, it does not. ...unlike exclusive jurisdiction clauses, non-exclusive jurisdiction is neither straightforward nor uniform." 311

Briggs argued strongly that, because optional choice of court agreements may have different effects, depending on exactly what the agreement provides, "it would be beneficial to lay aside the unhelpful terminology of 'non-exclusive jurisdiction agreement', and to focus instead on precisely what obligations the parties wished to create and impose on each other." 312 The focus on the obligations entailed in the choice of court agreement is consistent with the law in some, but not

\footnotetext{
309 See, for example, Rozehnalová et al (2020), Section 1.3.

310 Takahashi acknowledges the influence of the Brussels I Regulation in terms of the introduction in the 2012 amendments to the Japanese Code of Civil Procedure of the protective provisions relating to consumer and individual employment contracts: (2020), Section 1.

$311 \quad$ Briggs (2008), p 116, para 4.19.

$312 \quad$ Briggs (2008), p 120, para 4.23.
} 
all, countries represented in the national reports. Disagreeing with Briggs' argument, Joseph pointed out that the distinction between exclusive and non-exclusive jurisdiction agreements "was of central importance" to the Brussels I Recast, the Lugano Convention, and the Hague Choice of Court Agreements Convention. ${ }^{313}$ As Oprea notes, the distinction is important in practice for several reasons. First, the Hague Convention does not apply to optional agreements; ${ }^{314}$ and second, a number of specific rules have been developed which apply only to exclusive agreements. $^{315}$

In short, it seems clear that the category of optional choice of court agreements is here to stay. This collection suggests the need for further work at the international, regional, and national levels in order to improve the certainty, clarity, and consistency of the law relating to optional choice of court agreements, which is already important in practice and only likely to become more so.

Mary Keyes is a professor at Griffith Law School, at Griffith University, in Brisbane, Australia. Her teaching and research interests are in the areas of jurisdiction, particularly choice of court; and international family law and litigation.

\section{References}

Briggs A (2008) Agreements on jurisdiction and choice of law. Oxford University Press, Oxford

Briggs A (2012) The Subtle Variety of Jurisdiction Agreements. Lloyd's Maritime and Commercial Law Quarterly 364

Collins L (gen ed) (2012) Dicey, Morris \& Collins on the Conflict of Laws, 15th edn. Sweet \& Maxwell, London

Hartley T (2013) Choice-of-Court Agreements Under the European and International Instruments. Oxford University Press, Oxford

\footnotetext{
$313 \quad$ Joseph (2015), p 102, para 4.03.

314 Oprea (2020), Section 2, text to note 19.

315 In particular, see Brussels I Recast Regulation, Article 31(2).
} 
Hartley T, Dogauchi D (2010) Explanatory report on the Convention of 30 June 2005 on Choice of Court Agreements. In: Permanent Bureau of the Conference (ed), Proceedings of the twentieth session, Tome III. Intersentia, Antwerp

Joseph D (2015) Jurisdiction and Arbitration Agreements and Their Enforcement, 3rd edn. Sweet \& Maxwell, London

Keyes M, Marshall BA (2015) Jurisdiction Agreements - Exclusive, Optional and Asymmetrical. Journal of Private International Law 11: 345-378

Keyes, M (2015) Party Autonomy in Dispute Resolution: Implied Choices in the Context of Jurisdiction. Japanese Yearbook of International Law 58: 223-246

Liu X, Zhou Q (2014) The Actual Connection Principle and Forum Non Conveniens in Chinese Contractual Jurisdiction System. Legal Science 12: 50

Maher G, Rodger B (2010) Civil Jurisdiction in the Scottish Courts. W Green, Edinburgh Marshall BA, Keyes M (2017) Australia's Accession to the Hague Convention on Choice of Court Agreements. Melbourne University Law Review 41: 246

Nygh P (1999) Autonomy in International Contracts, Clarendon Press, Oxford

Tang ZS (2012) Effectiveness of Exclusive Jurisdiction Clauses in the Chinese Courts - A Pragmatic Study. International \& Comparative Law Quarterly 61: 459

Tang ZS, Xiao Y, Huo Z (2016) Conflict of Laws in the People's Republic of China. Edward Elgar, Cheltenham

Yeo TM (2005) The Contractual Basis of the Enforcement of Exclusive and Non-Exclusive Choice of Court Agreements. Singapore Academy of Law Journal 17: 306

\section{National reports cited in this chapter}

Buxbaum H (2020) United States: The Interpretation and Effect of Permissive Forum Selection Clauses, in this collection

Chen R-C (2020) Taiwan: Legislation and Practice on Choice of Court Agreements in Taiwan, in this collection

Chong A (2020) Singapore: A Mix of Traditional and New Rules, in this collection

Guillemard S, Sabourin F (2020) Canada - Civil Law (Québec): Les clauses d'élection de for facultatives en droit international privé québécois, in this collection 
Haas E, MacCabe K (2020) Switzerland: Choice of Court Agreements According to the Code on Civil Procedure, the Private International Law Act and the Lugano Convention, in this collection Mailhé F (2020) France: A Game of Asymmetries, Optional and Asymmetrical Choice of Court Agreements under French Case Law, in this collection

Marshall B (2020) Australia: Inconsistencies in the Treatment of Optional Choice of Court Agreements, in this collection

Merrett L, Carruthers J (2020) United Kingdom: Giving Effect to Optional Choice of Court Agreements - Interpretation, Operation and Enforcement, in this collection

Oprea EA (2020) Romania: Interpretation and Effects of Optional Jurisdiction Agreements in International Disputes, in this collection

Panapoulos G (2020) Greece: A Forum Favorable to Optional Choice of Court Agreements, in this collection

Rammeloo S (2020) Netherlands: Optional Choice of Court Agreements in a Globalizing World, in this collection

Rozehnalová N, Mahdalová S, Zavadilová L (2020) Czech Republic: The Treatment of Optional and Exclusive Choice of Court Agreements, in this collection

Saumier G (2020) Canada - Common Law: Choice of Court Agreements in Common Law Canada, in this collection

Schoeman E (2020) South Africa: Time for Reform, in this collection

Takahashi K (2020) Japan: Quests for Equilibrium and Certainty, in this collection

Tarman ZD, Oba ME (2020) Turkey: Optional Choice of Court Agreements in Turkish Law, in this collection

Tu G, Huang Z (2020) China: Optional Choice of Court Agreements in the Vibrant Age, in this collection

Van Calster G, Poesen M (2020) Belgium: Optional Choice of Court Agreements, Legal Uncertainty Despite a Modern Legal Framework, in this collection

Weller M (2020) Germany: Optional Choice of Court Agreements - German National Report, in this collection 